\title{
CONSTITUTIONAL IMPEDIMENTS TO DECENTRALIZATION IN THE WORLD'S LARGEST FEDERAL COUNTRY
}

\author{
SHARMILA L. MURTHY* \& MAYA J. MAHIN**
}

Decentralization is often advocated as a means of improving local democracy and enhancing what economists call allocative efficiency. In federal countries, where power is already divided between national and state governments, decentralization involves the devolution of power from state to local governments. The world's largest federal country, India, took an unusual step to advance decentralization: it passed the 74th Constitutional Amendment Act to confer constitutional status on municipalities. However, India's efforts to promote the devolution of power through a national urban renewal scheme have not succeeded for three reasons. The first is that India's decentralization process is incomplete. Political decentralization has been stymied by the language of the constitutional amendment itself; administrative decentralization has been hampered by the comparative advantage of entrenched state-level institutions; and fiscal decentralization has not occurred because financial responsibility — but not significant revenue - has been devolved. The second reason is that decentralization has been undertaken in a top-down manner, which has exacerbated Center-state relations and mitigated the goal of allocative efficiency. Third is the relative weakness of local governance structures, which has created a Catch-22 situation: as long as the local

\footnotetext{
Copyright (C) 2015 Shamila L. Murthy and Maya J. Mahin

* Assistant Professor, Suffolk University Law School; JD/MPA 2003, Harvard Law School and Harvard Kennedy School of Government. This article benefited from valuable feedback received at the Law and Society Association's 2014 Early Career Workshop, with special thanks to Stephen Cody, Jennifer Carlson, and Thomas Hilbink. Thank you also to Isher Judge Ahluwalia, Subhadra Banda, and Ramnath Subbaraman for insightful comments, and to James Casiello for helpful assistance with the citations.

** M.P.H. Candidate Yale School of Public Health ; B.A. with Honors 2012, University of North Carolina- Chapel Hill. Ms. Mahin was previously a Research Assistant to Professor Murthy when she was a Fellow at the Carr Center for Human Rights Policy, Harvard Kennedy School of Government.
} 
governments lack significant capacity, the states are reluctant to devolve power to them. Additional effort needs to be directed towards an effective model of cooperative federalism. With Prime Minister Narendra Modi poised to create "smart cities" and promote urban renewal, it is critical to understand why India's prior decentralization efforts have largely failed. The lessons learned over the past decade are an important guide to the future of cities in India as well as in other federal countries.

\section{TABLE OF CONTENTS}

INTRODUCTION

I. CONSTITUTIONAL EMPOWERMENT OF CITIES IN INDIA.

A. India's 74th Constitutional Amendment Act Paves the Way for Decentralization

B. Decentralization Theory Motivated India's Constitutional

Reforms

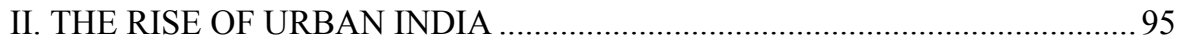

A. Urban Areas in India Were Historically Neglected............................ 95

B. In an Important Policy Shift, India Linked Urban Renewal to

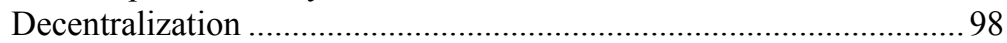

III. IMPEDIMENTS TO DECENTRALIZATION OF POWER TO CITIES ...... 102

A. Political Decentralization ............................................................... 103

1. States in India Have Historically Been Weak Vis-à-Vis the Central Government. 103

2. Cities Derive Their Power from the State ...................................... 111

B. Administrative Decentralization ...................................................... 114

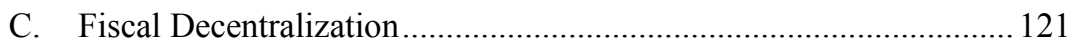

1. India's Fiscal Federal Structure is Highly Centralized.................. 122

2. Numerous Barriers Exist to Municipal Fiscal Empowerment....... 127

a. State Finance Commissions (SFCs) ...................................... 128

b. Expanding Revenue Base .................................................. 129

c. Private Sector Participation (Market-Based

Decentralization) ............................................................... 131

3. Greater Coordination is Needed ..................................................... 134 


\section{INTRODUCTION}

Cities are our future. They are engines of economic growth, channels for public participation, and vehicles for improving public services and quality of life. As of 2014, more than half of the world's population now lives in cities. ${ }^{1}$ Greater decentralization of power to cities is often promoted as a way to bring decisions closer to the people, ${ }^{2}$ thereby improving local democracy and enhancing what economists call allocative efficiency, i.e. the matching of services to local preferences. ${ }^{3}$ But cities are not autonomous legal actors; rather, in federal countries, their authority usually derives from state governments. As a result, the increased devolution of power to the local level can create tension with the states and highlight existing constitutional imbalances of power between the state and national governments.

Projected to have the fastest rate of urbanization in coming years, India represents an important case study for understanding the legal landscape in which cities are situated. ${ }^{4}$ A federal country, ${ }^{5}$ India took the unusual step of amending its constitution to give distinct constitutional status to municipalities. In 1992, the government of India passed the 74th Constitutional Amendment Act (CAA), which formally recognized urban

1. U.N. Dep't of Econ. \& Soc. Affairs, World Urbanization Prospects: The 2014 Revision, U.N. Doc. ST/ESA/SER.A/366, at xxi (2014); Somini Sengupta, U.N. Finds Most People Now Live in Cities, N.Y. TiMES (July 10, 2014), http://www.nytimes.com/2014/07/11/world/more-than-half-the-globalpopulation-growth-is-urban-united-nations-report-finds.html.

2. See, e.g., Gov't of India Second Admin. Reforms Comm'n, Local Governance: AN INSPIRING JOURNEY INTO THE FUTURE i (2007), http://arc.gov.in/6-1.pdf (examining the "need for real democratic decentralisation in the country in order to usher in genuine grass roots democracy"); P.K. Mohanty et AL., Municipal FinANCE IN INDIA: AN AsSESSMENT 1 (2007), http://saiindia.gov.in/ english/Members_Area/Public_Financial/Courseware\%20Session\%20Wise/SEssion\%2018\%20Munici pal\%20Finance/Municipal\%20Finance\%20in\%20India.pdf ("The Constitution (74 $4^{\text {th }}$ Amendment) Act, 1992 has mandated grassroot level democracy in urban areas ....").

3. Kyoko Kuwajima, Health Sector Management and Governance in Thailand, in ASIAN DeVELOPMENT EXPERIENCE VOL. 2: THE Role OF GOVERNANCE IN ASIA 190, 248 n.57 (Yasutami Shimomura ed., 2004).

4. See K.C. Sivaramakrishnan, Revisiting the 74th Constitutional Amendment for Better Metropolitan Governance, 48 ECON. \& POL. WKLY. 86, 86 (2013) (arguing that "Indian policymakers have been slow in responding to changing metropolitan forms and have largely visualised urbanisation as city expansion").

5. India is sometimes described as a quasi-federal country, as will be discussed infra. See S.P. AIYAR, Competitive and Cooperative Trends in the Indian Federal System, in ESSAYS ON INDIAN FEDERAlism 114, 115 (S.P. Aiyar \& Usha Mehta eds., 1965) (noting that Professr Wheare used the term "Quasi-federal" to deal with the "bewildering range of facts" present in the Indian system); V.G. Ramachandran, Aspects of Federalism, in ESSAYS ON INDIAN FEDERALISM 58 (S.P. Aiyar \& Usha Mehta eds., 1965) (explaining that “'quasi-federal' is a misnomer and only means 'virtually federal”'). 
local bodies. ${ }^{6}$ With this local-level empowerment came the opportunity to transform not only the way that citizens engaged with their government, but also the way that public services were delivered. But while this constitutional amendment was enacted over twenty years ago, only within the last decade has there been any real effort to implement these reforms in the urban sector. Despite a constitutional mandate and significant financial resources, the strengthening of municipalities has been difficult and the expected gains in democracy and public service delivery have not materialized.

This is a critical moment for understanding why India's efforts to decentralize power down to municipalities have met with only limited success. Buoyed by a landslide election in the summer of 2014 and a recent visit by U.S. President Barack Obama in January 2015, Indian Prime Minister Narendra Modi is poised to launch a series of programs designed to create modern cities that can foster economic growth. For example, India will soon be receiving U.S. support for the construction of three "smart cities," "7 which among other things, should be able to provide good infrastructure such as water, sanitation, reliable utility services, and health care. ${ }^{8}$ Modi's election also signaled the conclusion of the Jawaharlal Nehru National Urban Renewal Mission (JnNURM), India's flagship urban renewal program, which was created under the previous administration in 2005. Prime Minister Modi has since replaced the JnNURM with his own urban renewal scheme, the Atal Mission for Rejuvenation and Urban Transformation (AMRUT), which continues to tie urban renewal to decentralization. ${ }^{9}$ The lessons learned over the past decade are an important guide to the future of cities in India as well as in other federal countries.

6. The term "urban local bodies" (ULBs) is generally used by the government of India because there are three tiers of urban local bodies. In this article, the term "municipalities" or "cities" is used. The distinctions are not relevant for the purposes of this article because power can be devolved to any of the municipal bodies. See K.C. Sivaramakrishnan, Judicial Setback for Panchayats and Local Bodies, 45 ECON. \& POL. WKLY. 43, 45-46 n.5 (2010). India also passed the 73rd Constitutional Amendment Act in 1992, which paved the way for greater decentralization of power to rural local bodies, known as panchayats.

7. Obama in India: US, India Sign Pact for Developing Smart Cities in Ajmer, Allahabad \& Visakhapatnam, ECON. TIMES (Jan. 25, 2015), http://articles.economictimes.indiatimes.com/2015-0125/news/58433367_1_smart-cities-mous-agreements.

8. Draft Concept Note on Smart City Scheme 4 (Smart City Council, Working Paper, 2014), http://india.smartcitiescouncil.com/system/tdf/india/public_resources/Concept-Note-on-Smart-City Scheme_0.pdf?file=1\&type=node\&id=2229.

9. PM's Remarks at the Launch of AMRUT, Smart Cities Mission and Housing for All (Urban), PMINDIA NEWS UPDATES (June 25, 2015), http://pmindia.gov.in/en/news_updates/pms-remarks-at-thelaunch-of-amrut-smart-cities-mission-and-housing-for-all-urban/ [hereinafter PM's Remarks]. 
As the role of cities becomes increasingly important in our global economy, this paper highlights how constitutional design and history can impede the effective decentralization of power. With an analysis that draws on the legal, political economy, and urban planning literature, this article points to three key reasons that may explain why decentralization in India has not led to the expected gains in municipal empowerment and effectiveness. The first is the partial nature of India's decentralization. Service delivery improvements are more likely to occur when political, administrative, and fiscal decentralization are pursued simultaneously. In India, the language of the constitutional amendment itself has stymied political decentralization, the comparative advantage of entrenched statelevel institutions has hampered administrative decentralization, and fiscal decentralization has not occurred because financial responsibility, but not significant revenue, has been devolved to municipalities. The second reason is that decentralization in India has been top-down. Priority-setting at the national level mitigates the supposed allocative efficiency of decentralization, whereby decision-making is brought closer to the people. Moreover, this approach has exacerbated relations with the states, which often perceive national efforts to empower local bodies as a means of undermining state power. The third factor is the relative weakness of local governance structures, which has created a Catch-22 situation. Decentralization aims to empower local governments, but as long as local governments lack significant capacity, states will be reluctant to devolve power to them. In order for decentralization to succeed, more effort needs to be directed towards an effective model of cooperative federalism.

The article begins with Indian constitutional history, outlining in Section I the key elements of the 74th CAA, which gave constitutional status to municipalities. Section I not only probes the underlying rationales for the 74th CAA, but also situates India's experience in the context of broader economic and political theories of decentralization and subsidiarity. A global survey of cases examining the impact of decentralization makes clear that there are many aspects to decentralization - and how it is implemented is critical.

Section II explores the rise of urban India. For decades, India's policies towards cities echoed Mahatma Gandhi's famous remark that "India lives in its villages." Therefore, urban planning failed to keep step with migration to cities, resulting in poor public services and the proliferation of slums. Recognizing that urban areas are engines of future economic growth, India launched a massive urban renewal program in 2005 to improve service infrastructure and rehabilitate slums in major cities. The JnNURM marked a seismic shift in policy not only because it 
sought to promote urban renewal, but because it simultaneously promoted local governance reforms. It breathed life into the 74th CAA, which had been adopted over a decade earlier in 1992. Though the JnNURM created the potential for greater decentralization, it ultimately achieved only limited success.

Section III analyzes the roadblocks that India has faced in its efforts to decentralize power to the municipal level. Its sub-sections address, in turn, various barriers to achieving political, administrative, and fiscal decentralization. As discussed in Section III.A, states can, but are not required to, devolve power to municipalities under the 74 th CAA. States are often reluctant to do so because they perceive municipal empowerment as a reduction of their own power vis-à-vis the central government.

Section III.B traces the limited success of India's efforts at administrative decentralization to municipalities' lack of capacity and technical expertise. Because many public services are already delivered through state-level organizations (known as parastatals), states are hesitant to devolve responsibility to entities that are unprepared and untested.

Finally, Section III.C suggests that fiscal decentralization has not occurred because the devolution of financial responsibility has not been accompanied by a sizeable increase in municipalities' revenues. Instead, municipalities have been encouraged to diversify their funding bases and to tap into new revenue sources. But doing so is challenging in practice and contradicts the theoretical efficiency gains associated with a fiscal federal system.

The analysis highlights the critical need for effective cooperative federalism in India. The top-down, highly centralized way in which decentralization has been implemented has exacerbated the relationship between the national government and the states. But because the central government must work through the states to devolve power and funds to municipalities, the states' support is vital. Historically, India's strong central government has successfully wielded the power of the purse to implement its own policies. As a result, India's national urban renewal mission tied the delivery of municipal improvement funds to mandatory reforms at the local and state levels without the necessary level of state consultation and support. If India truly seeks to realize the promise of decentralization envisioned by the constitutional amendment made over two decades ago, the nation needs to develop a more efficient and cooperative model of federalism. The future of cities requires it. 


\section{CONSTITUTIONAL EMPOWERMENT OF CITIES IN INDIA}

\section{A. India's 74th Constitutional Amendment Act Paves the Way for Decentralization}

India is not only the world's largest democracy, but the world's largest federal country. ${ }^{10}$ Constitutionally asymmetric, the national government of India is a union of twenty-nine states ${ }^{11}$ and seven Union territories. ${ }^{12}$ Article 246 of India's Constitution (Seventh Schedule) contains three lists - a Union List, a State List, and a Concurrent List - that delineate the powers of each level of government. ${ }^{13}$ Notably, power over matters not enumerated in the State or Concurrent Lists are reserved to the central government. ${ }^{14}$ As a result, India's central government holds residual powers and has overriding authority in areas subject to the Concurrent List, where there is overlapping jurisdiction. ${ }^{15}$ India's national government is officially a "union" government, but is frequently referred to as the "central" government because the national government wields significant power as compared to the states. ${ }^{16}$

10. See Herman Bakvis \& William M. Chandler, Federalism and Comparative Analysis, in Federalism AND the Role OF THE StATE 3, 5 (Herman Bakvis \& William M. Chandler eds., 1987).

11. The number of states in India's federation has increased in recent years as large states split. For example, in June 2014, India created yet another new state, Telangana, which was carved out of Andhra Pradesh. See New State of Telangana is Born in Southern India, BBC NEWS (June 2, 2014), http://www.bbc.com/news/world-asia-india-27658817.

12. Sharada RATH, FEDERAlism TODAY 19 (1984); Rekha Saxena, Is India a Case of Asymmetrical Federalism?, 47 ECON. \& POL. WKLY. 70, 71 (2012), http://www.unifr.ch/federalism network/assets/files/tpl/forum_uploads/Rekha\%20EPW\%20ARTICLE\%20ON\%20ASYMMETRICAL \%20FEDERALISM.pdf (noting that given the presence of the Union territories and the unique status of Jammu and Kashmir, India's Constitution is constitutionally asymmetric, a term that refers to the differing size and power of the governmental subunits).

13. INDIA CONST. art. 246.

14. INDIA CONST. Seventh Schedule, List I, 997.

15. Pratibha Agarwal, Fiscal FEDERAlism in India: IMPACT OF Union Transfers on STATE FINANCES 38 (2012); P.K. Chaubey, Evolution of Union-State Fiscal Relations in India: Two Steps Forward and One Step Backward, in FisCAL FEDERALISM IN InDIA 21, 21 (P.K. Chaubey ed., 2003) [hereinafter Chaubey, Union-State Fiscal Relations]; see also Debes Mukhopadhayay, CentreState Financial Relations in India: An Account of Major Debates, in FISCAL FEDERALISM IN INDIA, supra, at 55, 57 (noting that "the Indian Constitution exhibits 'a federation with a strong centralizing tendency", (citation omitted)).

16. A federal country, India is a union of quasi-sovereign states that are guaranteed certain powers under the Constitution. India's national government is frequently referred to as the "central" government, which illustrates the centralized nature of India's federal structure and the power that the national government wields vis-à-vis the states. See P.K. Chaubey, Federalism in India: An Introduction, in FISCAL FEDERALISM IN INDIA, supra note 15, at 1, 3-4 [hereinafter Chaubey, Federalism in India] (noting the "[o]ver-centralisation of Federal Structure" and that the government of India is "de jure the Union Government but de facto the Central Government"). 
In 1992, the Indian government passed the 73rd and 74th Constitutional Amendment Acts (CAA), which gave constitutional status to rural and urban local bodies, known as panchayats and municipalities, respectively. ${ }^{17}$ This unique feature of India's Constitution is absent from some other federations such as the United States, Canada, and Australia. ${ }^{18}$ The amendments to India's Constitution were codified in Article 243. ${ }^{19}$ Until that point, local governments in India were created by virtue of the "ultra vires" principle, ${ }^{20}$ and, therefore, their governance was left to the discretion of states. ${ }^{21}$

The 74th CAA's passage marked the first time that urban local bodies received constitutional recognition. ${ }^{22}$ The 74 th CAA defines municipalities; provides a vehicle for devolving significant administrative powers, responsibilities, and sources of revenue to municipalities; ${ }^{23}$ and lays out a democratic governance framework in which municipalities should operate. ${ }^{24}$ Specifically, the 74 th CAA mandates the creation of three tiers of

17. Rural local bodies in India are referred to as panchayats raj. For a discussion of judicial review of constitutional amendments, see e.g., SUDHIR KRISHNASWAMY, DEMOCRACY AND CONSTITUTIONALISM IN INDiA: A STUDy OF THE BASIC STRUCtURE Doctrine xviii (2009) ("A significant part of the academic and popular criticism of judicial activism of the Supreme Court is directed to the courts' use of the basic structure doctrine to review constitutional amendments ... much of this criticism emerges from a failure to adequately map the contours of constitutional judicial review as practised in the courts today.").

18. Roger Gibbins, Local Governance and Federal Political Systems, 53 INT’L Soc. SCI. J. 163, 164 (2001) (noting that municipal governments receive no explicit mention in the constitutions of Canada, the United States, and Australia).

19. See InDIA CONST. art. 243, amended by The Constitution (Seventy-Third Amendment) Act, 1992 (dedicating article 243-2430 to panchayats); INDIA CONST. art. 243, amended by The Constitution (Seventy-Fourth Amendment) Act, 1992 (dedicating article 243P-ZG to municipalities).

20. The term "ultra vires" means "beyond the scope of power allowed or granted ... by law." Ultra vires, BLACK'S LAW DICTIONARY (10th ed. 2014).

21. Gov't of India Second Admin. Reforms Comm'n, supra note 2, at 13; Nat'1 Inst. of Urban Affairs, Impact of the Constitution (74th amendment) Act on the Working of Urban Local Bodies vi (2005), http://www.niua.org/research_studies_2006.asp.

22. Gavin Shatkin \& Sanjeev Vidyarthi, Introduction: Contesting the Indian City: Global Visions and the Politics of the Local, in CONTESTING THE INDIAN City: GLOBAL Visions AND THE POLITICS OF THE LOCAL 1, 10 (Gavin Shatkin ed., 2014). In contrast, rural local bodies, known as panchayats, were recognized as "units of self-government" in India's original constitution. See, e.g., INDIA CONST. 1949 art. 40 ("The State shall take steps to organise village panchayats and endow them with such powers and authority as may be necessary to enable them to function as units of self-government.").

23. INDIA CONST. art. 243W-243ZG, amended by The Constitution (Seventy-Fourth Amendment) Act, 1992 (setting forth municipalities' specific functions and responsibilities).

24. David Savage \& Shubhagato Dasgupta, Governance Framework for Delivery of Urban Services, in INDIA INFRASTRUCTURE REPORT 42, 43 (2006) (identifying salient features of the 74th CAA); Shatkin \& Vidyarthi, supra note 22, at 10; K.C. SiVARAMAKRISHNAN, POWER TO THE PEOPLe?: The Politics AND PROGRESS OF DECENTRALISATION 132-45 (2000) (discussing history of how powers for municipalities evolved into the schedule). 
local bodies, each made up of elected officials. ${ }^{25}$ In addition, the new constitutional provisions devolve greater functional responsibilities and financial powers to municipalities and require the creation of several administrative bodies to oversee deliberative planning, such as Wards Committees, District Planning Committees, and Metropolitan Planning Committees. ${ }^{26}$ State Finance Commissions were also created as vehicles for channeling money from the Central Finance Commission to the local bodies. ${ }^{27}$ With the goal of creating a more representative government at the local level, the 74th CAA also requires the regular and fair conduct of municipal elections and the reservation of seats for persons belonging to scheduled castes, scheduled tribes, backward classes, and women. ${ }^{28}$

But while the 74th CAA provides a platform for empowering municipalities, it is important not to overstate their constitutional powers. The amendment does not automatically give local bodies autonomy. Rather, Article $243 \mathrm{~W}$ gives states the discretion to devolve political, administrative, and fiscal power to municipalities. ${ }^{29}$ The Supreme Court of India underscored the discretionary nature of the states' devolution power in the Ranga Reddy case, which involved the interpretation of analogous provisions for rural panchayats, under the Eleventh Schedule. ${ }^{30}$ Notably, even the dissenting justice, who otherwise argued that the states were obligated to devolve administrative powers, stated that because the Constitution did not devolve legislative or judicial authority, "[i]t is impermissible to characterize the Panchayats as the 3rd tier of the federal structure, under the Indian constitutional scheme even after the 73rd

25. INDIA CONST. art. 243Q (using the term "Nagar Panchayat" to describe "an area in transition from rural area to urban area"; "Municipal Council" describes a "smaller urban area"; "Municipal Corporation" describes "larger urban area[s]"); Abhijit Datta, Municipal Reform in India: Comparative Models and Processes, 30 ECON. \& POL. WKLY. 2395, 2395 (1995).

26. NAT'L INST. OF URBAN AFFAIRS, supra note 21, at vi.

27. See Sivaramakrishnan, supra note 24 , at $167-71$.

28. India CONST. art. 243T; GOV'T OF INDIA SECOND ADMIN. REFORMS COMM'N, supra note 2, at 9; NAT'L INST. OF URBAN AFFAIRS, supra note 21, at ix.

29. Under Article $243 \mathrm{~W}$ of the Constitution, "the Legislature of a State may, by law, endow" a municipality with any of the eighteen functions listed in the Twelfth Schedule of the Constitution. INDIA CONST. art. 243W; P.K. Mohanty, A Municipal Financing Framework, in URBANISATION IN InDia: CHALLENGES, OPPORTUNITIES AND THE WAY FORWARD 119, 123 (Isher Judge Ahluwalia et al. eds., 2014).

30. See Ranga Reddy Dist. Sarpanches Ass'n v. Gov’t of Andhra Pradesh, (2004) 1 ALT 659, 96 of the concurrence ("It is for the State Legislature to decide by expressing its will through legislation or subordinate legislation that to what extent the Panchayat Raj Institutions should be conferred with power and authority." (Gupta, J., concurring)); Sivaramakrishnan, supra note 6, at 46 (disagreeing with the majority opinion, which "held that it was not obligatory on the part of a state government to assign functions" and agreeing with the dissent, which argued that this holding reduced key parts of the Constitution to "surplusage"). 
amendment." 31 The same analysis would likely hold true for urban local bodies under the 74th CAA because the amendments are structurally similar.

The Twelfth Schedule of the Constitution permits a state to devolve up to eighteen specified powers to a municipality, including: urban planning, regulating land-use, planning for economic and social development, alleviating urban poverty and upgrading slums, building roads and bridges, supplying water, and managing solid waste. ${ }^{32}$ The constitutional provision sets forth guideposts and outer limits on what powers may be devolved, stating that the municipalities should have "such powers and authority as may be necessary to enable them to function as institutions of selfgovernment," but that their power may be restricted to "the preparation of plans for economic development and social justice" and "the performance of functions and the implementation of schemes as may be entrusted to them including those in relation to the matters listed in the Twelfth Schedule." 33

These constitutional amendments represent an important formal shift in the distribution of power in India. If important political, administrative, and fiscal functions were actually devolved by states, then municipalities could realize the perceived benefits of decentralization, including the promotion of grassroots democracy and improved delivery of public services in urban areas.

\section{B. Decentralization Theory Motivated India's Constitutional Reforms}

The passage of the 74th CAA reflects India's embrace of the theory of decentralization and the doctrine of subsidiarity, a principle of international law that reflects a preference for making decisions at the lowest possible level of government. ${ }^{34}$ Public functions are carried out at the lowest tier

31. Ranga Reddy, 1 ALT at 9 ฯ 20, 37, 60 of the dissent (Raghuram, J., dissenting).

32. Mohanty, supra note 29, at 127 (classifying eighteen functions in Twelfth Schedule according to three functions: essentially municipal functions, agency functions, and shared or concurrent functions); Govinda Rao \& Richard Bird, Governance and Fiscal Federalism, in URBANISATION IN INDIA: CHALLENGES, OPPORTUNITIES AND THE WAY FORWARD, supra note 29, at 203, 211; MOHANTY ET AL., supra note 2, at ii (noting that a state can delegate an urban municipality to implement central or state government schemes).

33. INDIA CONST. art. 243W.

34. See Yishai Blank, Federalism, Subsidiarity, and the Role of Local Governments in an Age of Global Multilevel Governance, 37 FORDHAM URB. L. J. 509, 533 (2010) ("[S]ubsidiarity mandates that 'action should be taken at the lowest level of government at which particular objectives can adequately be achieved." (internal citation omitted)); Albert Breton et al., Decentralization and Subsidiary: Toward a Theoretical Reconciliation, 19 J. INT’L L. 21, 21-22 (1998) (““[S]ubsidiarity is the specific claim that the burden of proof in the process of making this trade-off [between the claims of decentralization and those of centralization] should lie in favour of decentralization,' and 'that when in 
possible and delegated upwards only when smaller units of governance cannot perform the tasks effectively. ${ }^{35}$ Subsidiarity can only be achieved if there is effective decentralization, like that envisioned by the 74th CAA. ${ }^{36}$

India's reforms under the 74th CAA were largely motivated by the goal of political decentralization - a desire to bring government closer to the people and, thereby, provide more opportunities for civic participation and for the empowerment of local officials. ${ }^{37}$ In India, municipal empowerment through the principle of subsidiarity is perceived as a way to create greater "grassroot[s] . . democracy",38 and more "citizen-centric[]",39 government. It is also seen as a vehicle for providing citizens with a sense of ownership over government programs and giving them greater ability to participate in decision-making. ${ }^{40}$ Subsidiarity and decentralization have the potential in India to improve efficiency, enhance local self-reliance, spur competition, and promote innovation. ${ }^{41}$

doubt, decentralization should be preferred."”); Paolo G. Carozza, Subsidiarity as a Structural Principle of International Human Rights Law, 97 AM. J. INT'L L. 38, 41-42 (2003). The usage of this term goes as far back as ancient Greece, but it is strongly associated with the Catholic social theorists of the nineteenth century. One such theorist, Pius XI, defined subsidiarity as the principle that "[j]ust as it is gravely wrong to take from individuals what they can accomplish by their own initiative and industry and give it to the community, so also it is an injustice and at the same time a grave evil and disturbance of right order to assign to a greater and higher association what lesser and subordinate organizations can do." Id. at 42 (quoting Pius XI, Quadragesimo Anno: Encyclical Letter on Reconstruction of Social Order, in 3 THE PAPAL ENCYCLICALS 1903-1939, 428 (1931)).

35. GOV'T OF INDIA SECOND ADMIN. REFORMS COMM'N, supra note 2, at 14 ("The central idea of subsidiarity is that citizens as sovereigns and stake-holders in a democracy are the final decisionmakers.").

36. Id. at 15 .

37. K. Dharmarajan, Power to the People: 74th Amendment, in NAT'L INST. OF URBAN AfFAIRS, The 74th Constitutional Amendment: Power to the People 63, 63 (1994) ("The 74th Constitutional Amendment... seeks to provide constitutional recognition to the third-tier of the Government and bring political power closer to the people."); K.C. SIVARAMAKRISHNAN, REVISIONING INDIAN CITIES: THE URBAN RENEWAL MISSION 94-95 (2011) ("The 74th Constitutional Amendment has been acclaimed as a comprehensive prescription for empowerment of the ULBS.”). See generally SIVARAMAKRISHNAN, supra note 24.

38. Gov't of India SECOND Admin. Reforms Comm'n, supra note 2, at i; Mohanty et AL., supra note 2 , at 1 .

39. GOV'T OF INDIA SECOND ADMIN. REFORMS COMM'N, supra note 2, at 13.

40. Savage \& Dasgupta, supra note 24, at 42 ("Recent years have witnessed an increasing interest in and growing consciousness of the need and importance of local self-government as a provider of services to the community as well as an instrument of democratic self-government."). See generally Priyam Das, Decentralization and Citizen Participation in Urban Service Delivery in India: Is Institutionalizing Enough?, in DEMOCRATIC LOCAL GOVERNANCE: REFORMS \& INNOVATIONS IN ASIA 112, 122 (G. Shabbir Cheema ed., 2013).

41. Gov't of India SECOND Admin. ReForms COMM'N, supra note 2, at 14-16 ( "[I]f democracy is to be real and meaningful, the locus of power should shift as close to the citizen as possible in order to facilitate direct participation, constant vigil and timely intervention."). 
India's approach is in line with broader political theory on decentralization, which suggests that by encouraging public participation, decentralization leads to governance that is more creative, responsible, and effective. ${ }^{42}$ For example, decentralization allows local administrators to test innovative ideas without justifying their adoption on a national scale. ${ }^{43}$ Across the world, decentralization is a means for "democratic local governance," which gives citizens and their elected local representatives more power in public decision-making. ${ }^{44}$ The rationale is that it is generally easier for the average citizen to gain access to local-as opposed to national-political forums. Local public participation has the advantage of highlighting gaps in basic service provision, which local leaders can then try to fix. Under certain situations, decentralization may also improve human rights outcomes, though this largely depends on the way in which decentralization efforts are implemented. ${ }^{45}$

The promise of more effective outcomes has fueled the drive towards decentralized governance in India. ${ }^{46}$ As stated in the Twelfth Five Year Plan of India, "[t]he principle of subsidiarity is now well established in development literature across the world. The role of local governments in ensuring efficient and accountable delivery of basic services is now well

42. Hans F. Illy, Decentralisation: A Worldwide Trend, in FEDERALISM AND DeCEntRalisation: Centre-State Relations in India AND Germany 26, 30 (Gert W. Kueck et al. eds., 1998).

43. Id. at $30-31$.

44. Harry Blair, Participation and Accountability at the Periphery: Democratic Local Governance in Six Countries, 28 WORLD DEV. 21, 21, 23-26 (2000), http://isites.harvard.edu/ fs/docs/icb.topic793411.files/Wk\%205_Oct\%201st/Blair_2000_Local\%20Governance\%20in\%20Six\% 20Countries.pdf; see also Nancy Thede, Decentralization, Democracy and Human Rights: A Human Rights-Based Analysis of the Impact of Local Democratic Reforms on Development, 10 J. HuM. DEV. \& CAPABABILITIES 103, 104-05 (2009) ("[D]ecentralization as democratic reform . . . has been inspired by two separate logics: on the one hand, that of the pro-democracy movements in southern countries; and on the other, the governance reforms piloted by the international financial institutions (IFIs).").

45. See G.A. Res. 217 (III) A, Universal Declaration of Human Rights (Dec. 10, 1948), art. 21 (stating in Article 21 that "[e]veryone has the right to take part in the government of [one's] country"). But see INT'L COUNCIL ON HUMAN RightS POLICY, LOCAL RULE: DECENTRALISATION AND HUMAN RIGHTS 19-21, 23-30, (2002), http://reliefweb.int/sites/reliefweb.int/files/resources/15C8B99E9E0E8 85CC1257 50B00503166-ICHRP_Jan2002.pdf (finding that decentralization does not always lead to the increased realization of human rights, but that it is more likely to happen when the decentralization effort (1) "enhances political rights" (2) "leads to more effective government" (3) "helps to achieve economic and social rights" (4) "promotes accountability", and (5) "increases local autonomy and empowers disadvantaged group[s]").

46. See Gov'T OF India SECOND ADMIN. REFORMS COMM'N, supra note 2, at v (identifying core principles underpinning this agenda which include: "democratic decentralisation as the centre-piece of governance reforms in the country; the principle of subsidiarity which means that what can best be done at the lower levels of government should not be centralised at higher levels; a clear delineation of functions entrusted to the local bodies; effective devolution in financial terms and convergence of services for the citizens as well as citizens centric governance structures"). 
understood." ${ }^{, 47}$ A key premise of the 74th CAA is that "[1]ocal governments are ideally suited to provide services like water supply, solid waste management, sanitation, etc., as they are closer to the people and in a better position to appreciate their concerns and even economic principles state that such services are best provided at the level of government closest to the people."48 Moreover, by giving citizens greater responsibility for the hard choices that need to be made, ${ }^{49}$ fiscal responsibility is expected to improve because people are better positioned to see the link between taxes and municipal resource generation and service outcomes. ${ }^{50}$

Decentralization is expected to improve economic efficiency because of local government's increased accountability to its citizens and better knowledge of their preferences. Devolution of certain tasks to local governments is often advocated on the grounds that it will lead to an improvement in "allocative efficiency" and "productive efficiency." Allocative efficiency is defined as "better matching of public services to local needs," 51 while productive efficiency refers to the ability to produce a good at the lowest possible cost. The idea is that local officials are better positioned than central government officials to implement certain initiatives, provided that the effective coordination mechanisms are in place. $^{52}$ Moreover, citizens can theoretically hold local officials accountable by "vot[ing] with their feet" - moving to states that offer the

47. Planning Comm'N, Gov't of India, Twelfth Five Year Plan (2012-2017): Faster, MORE INCLUSIVE AND SUSTAINABLE GROWTH - VOluME I 328 (2013), http://planning commission.gov.in/plans/planrel/12thplan/pdf/12fyp_vol1.pdf; see also HIGH POWERED EXPERT COMM. (HPEC) FOR ESTIMATING THE INV. REQUIREMENTS FOR URBAN INFRASTRUCTURE SERVS., REPORT ON INDIAN URBAN INFRASTRUCTURE AND SERVICES 104 (2011), http://icrier.org/pdf/ FinalReport-hpec.pdf [hereinafter HPEC REPORT] (noting that the creation of institutions such as a Local Body Ombudsman can play a significant role in efforts to improve accountability).

48. GOV'T OF INDIA SECOND ADMIN. REFORMS COMM'N, supra note 2, at 10; see also THIRTEENTH FIN. COMM'N OF INDIA, REPORT OF THE THIRTEENTH FINANCE COMMISSION (2010-2015) 149 (2009) ("Providing basic services at the grassroots level makes them the primary interface of the citizens' interaction with the government. The principle of subsidiarity implies that matters are best handled by the least centralised competent authority. Following this, these institutions need to be adequately empowered - both functionally and financially - to enable them to fulfil the role envisaged for them in the Constitution.").

49. GOV'T OF INDIA SECOND ADMIN. REFORMS COMM’N, supra note 2, at 14.

50. Id. at 15 .

51. Kuwajima, supra note 3, at 192 .

52. See Illy, supra note 42 , at 30 ("The efficiency of the central government could be increased through decentralisation by relieving top management officials of routine tasks that could be more effectively performed by field staff or local officials."); Anand N. Asthana, Decentralisation, HRD and Production Efficiency of Water Utilities: Evidence from India, 14 WATER POL'Y 112, 112 (2012) (noting that in some cases decentralization is associated with the neglect of human resources development that ultimately lowers productive efficiency). 
unique bundle of goods that they prefer. ${ }^{53}$ Decentralization is also expected to reduce bureaucracy and improve knowledge of local costs, all of which leads to higher levels of productive efficiency. ${ }^{54}$

But research from around the world has highlighted situations in which the theoretical benefits of decentralization have not materialized. Decentralization does not always achieve its economic efficiency goals; rather, decentralization can exacerbate corruption ${ }^{55}$ and tax evasion. ${ }^{56}$ Nor does decentralization necessarily guarantee more responsible governance. Because citizens in poor countries lack resources, they cannot ensure that the bundle of services provided by their local government matches their preferences by "voting with their feet." ${ }^{57}$ Additionally, local governments in poor countries may not be concerned about the departure of residents who are a perceived drain on resources. ${ }^{58}$ Indeed, even if residents were to move due to dissatisfaction with service delivery and local governments were to revise policy in response, "strong incentives to orient their policies toward more mobile groups" make it unlikely that the changes would

53. Rao \& Bird, supra note 32, at 205; Pranab Bardhan, Governance Issues in Delivery of Public Services, 13 J. AFR. ECONS. i167 (2004).

54. Satu Kahkonen \& Anthony Lanyi, Decentralization and Governance: Does Decentralization Improve Public Service Delivery?, PREM NOTES, June 2001, No. 55; see also Alfred P. Montero \& David J. Samuels, The Political Determinants of Decentralization in Latin America: Causes and Consequences, in DeCentralization and Democracy in LATin AMERica 3, 25-26 (Alfred P. Montero \& David J. Samuels eds., 2004) (noting that the evidence of decentralization leading to increased accountability has been strong in the Latin American context); Iwan Barankay \& Ben Lockwood, Decentralization and the Productive Efficiency of Government: Evidence from Swiss Cantons, 91 J. PUB. ECON. 1197, 1197 (2007), http://www.sciencedirect.com/science/article/pii/S00472 72706001654 (exploring the relationship between decentralization and productive efficiency).

55. See generally Kilkon Ko \& Hui Zhi, Fiscal Decentralization: Guilty of Aggravating Corruption in China?, 22 J. CONTEMP. CHINA 35, 35 (2013) (noting that fiscal decentralization can increase corruption if law enforcement is weak). See also Christian Lessman \& Gunther Markwardt, One Size Fits All? Decentralization, Corruption, and the Monitoring of Bureaucrats, 38 WorLD DEV. 631, 631 (2009) (finding that decentralization can increase corruption in countries in which press freedom is restricted).

56. See Jan K. Brueckner, Fiscal Decentralization in Developing Countries: The Effects of Local Corruption and Tax Evasion, 1 ANNALS ECON. \& FIN. 1, 1 (2000) (finding that the phenomena of local corruption and tax evasion did "indeed limit the benefits of fiscal decentralization").

57. Bardhan, supra note 53, at i168; See Rao \& Bird, supra note 32, at 205.

58. Omar Azfar et al., Political Disciplines on Local Government: Evidence from the Philippines, in Devolution and Development: Governance Prospects in Decentralizing States 197, 199 (Mwangi S. Kimenyi \& Patrick Meagher eds., 2004). The authors' analysis focused on the Philippines, and they found that in this case, migration in response to service delivery offerings is fairly limited and instead seems to be mostly driven by unemployment. Id. The authors also note that even if citizens in developing countries are mobile, they likely will not be mobile enough to achieve the desired level of allocative efficiency. Id. 
reflect the interests of all citizens. ${ }^{59}$ Additionally, allocative efficiency may not be achieved in countries with heterogeneous local communities because differences in preferences between two local communities may be too negligible. ${ }^{60}$ Finally, decentralization may be problematic in countries pursuing large scale redistributive policies because local governments may be particularly ill-suited to the task of redistribution. ${ }^{61}$

Similarly, decentralization may not have the intended political impact of promoting participatory, grassroots democracy. ${ }^{62} \mathrm{~A}$ clear distinction exists between technical participation, which merely encourages "citizen voice," and ensuring that the opinions of the poor and socially marginalized are heard by those in power. ${ }^{63}$ If local citizens disagree with the way that the local authority is managing a resource or service, it may be tempting for officials to assume that the community lacks knowledge or capacity. ${ }^{64}$ While the poor or socially marginalized have more opportunities to publicly express their opinions, they may, nonetheless, have no more power in the decision-making process. Decentralized decision-making may be

59. Sebastian Eckardt, Accountability and Decentralized Service Delivery 49-50 (2006).

60. See, e.g., Jeff Dayton-Johnson, Determinants of Collective Action on the Local Commons: a Model with Evidence From Mexico, 62 J. DEV. ECON. 181, 181-82 (2000) (noting in a study on Mexican irrigation societies that more heterogeneous societies are likely to experience lower group performance and infrastructure maintenance); see also Melissa Leach, et al., Environmental Entitlements: Dynamics and Institutions in Community-Based Natural Resource Management, 27 WORLD DEV. 225, 226 (1999) (critiquing the assumption often made in this literature about the existence of a relatively homogenous community that can be a subject of reform).

61. See Amaresh Bagchi, Rethinking Federalism: Changing Power Relations Between the Center and the States, 33 PUBLIUS: J. FEDERALISM 21, 38 (2003), http://publius.oxfordjournals.org/content/33/ $4 / 21$.abstract (noting that there are "trade-offs" to delegating power to regional and local governments); see also Nirvikar Singh, Decentralization and Public Delivery of Health Care Services in India, 27 HEALTH AFF. 991, 991-99 (2008) (suggesting that a failure to implement decentralization at the local level disadvantaged public health service delivery in the early 2000s).

62. Das, supra note 40, at 114 ("Participation, however, has sometimes served to disenfranchise groups already marginalized by manufacturing consensus for policies that were created elsewhere and overlooking alternatives." (internal citations omitted)).

63. Richard Crook, Decentralisation and Poverty Reduction in Africa: The Politics of LocalCentral Relations, 23 PUB. ADMIN. \& DEV. 77, 79 (2003), http://onlinelibrary.wiley.com/doi/10.1002/ pad.261/abstract (internal citation omitted); see also Leach et al., supra note 60, at 228 ("[A]11 too often it is implied that the public airing of conflict is sufficient, and that social consensus and solidarity will necessarily result." (internal citation omitted)).

64. Jon Anderson, Four Considerations for Decentralized Forest Management: Subsidiarity, Empowerment, Pluralism, and Social Capital, in DeCENTRAlizATION AND DeVolution of Forest MANAGEMENT IN AsIA AND THE PACIFIC (T. Durst et al. eds., 2000) ("[F]orest services sometimes assume that because local groups do not agree with central expert authorities on how forests should be managed, that they must lack capacities or knowledge. Indeed, if local citizens disagree with the way that the local authority is managing a resource or service, it may be tempting for the officials to simply assume that the community lacks knowledge or capacity."), http://www.fao.org/docrep/003/x6898e/ x6898e02a.htm\#P69_19234. 
subject to elite capture, i.e., the misappropriation of resources by the community's elite in order to serve their own interests, which may reproduce power structures. ${ }^{65}$

Different forms of decentralization exist, including political, administrative, and fiscal decentralization, and much depends on the manner in which any given form is implemented. ${ }^{66}$ Partial decentralization may also stymie the intended benefits. ${ }^{67}$ For example, if the central government devolves some powers but retains control over others, local governments will be less able to respond to local preferences and the goal of allocative efficiency will not be achieved. ${ }^{68}$

In the Indian context, decentralization has not achieved its promised benefits because - as the analysis below illustrates - decentralization has only been partially implemented. Moreover, while 74th CAA was passed in

65. GOV'T OF INDIA SECOND AdMIN. REFORMS COMM'N, supra note 2, at iii (“[I]n situations of sharp local inequalities, decentralisation sometimes heightens the concentration of power, and discourages rather than fosters participation among the underprivileged. To illustrate, in some tribal areas where upper caste landlords and traders dominate village affairs, the devolution of power associated with the Panchayati Raj amendments has consolidated their hold and reinforced existing biases in the local power structure.”). See generally INT'L COUNCIL ON HUMAN RIGHTS POL'Y, supra note 45 , at 10 (noting that decentralization may undermine democracy by allowing local elites to capture the government, and emphasizing that in order for decentralization to be associated with human rights realization, participatory governance and accountable local governance need to be encouraged); Crook, supra note 63 (discussing empirical studies from Sub-Saharan Africa in which marginalized social groups have been the most excluded from the political process); Sanjay Kumar, Does "Participation" in Common Pool Resource Management Help the Poor? A Social Cost-Benefit Analysis of Joint Forest Management in Jharkhand, India, 30 WORLD DEV. 763 (2002), (finding that joint management of forests in India "reflects the social preference of the rural nonpoor"); Everisto Mapedza \& Kim Geheb, Power Dynamics and Water Reform in the Zimbabwean Context: Implications for the Poor, 12 WATER POL'Y 517 (2010) (discussing a case study on the decentralization of the water sector in Zimbabwe where a new law led to more small-scale farmers attending local meetings, but the process was still driven, and in some instances manipulated, by commercial farmers who were economically better off); George Mathew, Panchayati Raj Institutions and Human Rights in India, 38 ECON. \& POL. WKLY. 155 (2003) (noting that evidence from rural India suggests that greater devolution of power to the Panchyati Raj has exacerbated inter-caste inequities, and in some cases, resulted in caste-related violence around local elections. For example, "[i]n Melavalavu [a village in Tamil Nadu], the dominant castes of the area murdered the panchayat president and the vice-president who both belonged to a lower caste, merely because they dared to fight the panchayat elections.").

66. Different Forms of Decentralization, THE WORLD BANK GRP., http://www1.worldbank.org/ publicsector/decentralization/what.htm\#1 (last visited Sept. 24, 2015).

67. Shantayanan Devarajan et al., The Politics of Partial Decentralization, in DOES Decentralization Enhance Service Delivery And Poverty Reduction? 102, 107 (Etisham Ahmad \& Giorgio Brosio eds., 2009) (defining partial decentralization as "the situation when local governments are not held accountable for a complete set of budgetary allocations and their outcomes").

68. See generally Richard C. Crook, Four Years of the Ghana District Assemblies in Operation: Decentralization, Democratization and Administrative Performance, 14 PuB. AdMIN. \& DEV. 339 (1994), for the notion that local autonomy is achieved by allocating power in local government authority. 
1992, it was not seriously implemented until the JnNURM, a massive scheme adopted in 2005 with twin goals: the improvement of urban infrastructure and basic services through a series of reforms designed to promote municipal empowerment. ${ }^{69}$ But the JnNURM faced a large hurdle: the continually deteriorating performance of municipalities. ${ }^{70}$ The next section considers the challenges facing urban India before exploring existing barriers to political, administrative, and fiscal decentralization.

\section{THE RISE OF URBAN INDIA}

\section{A. Urban Areas in India Were Historically Neglected}

"India lives in its villages." Mahatma Gandhi's famous phrase defined India for many decades and illustrates the historical bias against urban area development. ${ }^{11}$ To reduce urban migration, cities were not provided with much infrastructure or industrial support. ${ }^{72}$ However, the last two decades have seen a renewed interest in urban areas fueled by economic liberalization, ${ }^{73}$ recognition that cities are engines of growth, and decentralization trends. $^{74}$ India will soon include some of the topperforming, "growth-contributing" cities in the world. ${ }^{75}$

More than ever before, cities are perceived as the building blocks of the global economy. This development is primarily attributable to two key trends. First, the proportion of the world's population that lives in cities is growing and will continue to grow. Indeed, the world just reached a

69. SIVARAMAKRISHNAN, supra note 24, at 14-15; see also id. at 91-104 (noting that adherence to the 74th CAA was among the mandatory reforms required by the JnNURM and more broadly discussing reform efforts).

70. NAT'L INST. OF URBAN AFFAIRS, supra note 21, at vi.

71. SIVARAMAKRISHNAN, supra note 37, at 1; Lorraine Kennedy \& Marie Helen Zerah, The Shift to City-Centric Growth Strategies: Perspectives from Hyderabad and Mumbai, 43 ECON. \& POL. WKLY. 110, 111-12 (2008), http://www.indiaenvironmentportal.org.in/files/The\%20shift\%20to\%20 city\%20 centric_0.pdf.

72. Kennedy \& Zerah, supra note 71 , at 111-12; see also Rakesh Mohan \& Shubhagato Dasgupta, The 21st Century: Asia Becomes Urban, 40 ECON. \& POL. WKLY. 213, 217 (2005) ("[I]n most developing countries especially those in Asia, urbanisation is still often viewed as a disease, and a trend that needs to be reversed.").

73. MOHANTY ET AL., supra note 2, at ii ("After liberalisation of the economy, India made strides in economic growth; a large part of it has been through the contribution of urban areas.").

74. See generally Ministry of Urban EMP'T \& Poverty AlleViation \& Ministry of Urban Dev., Jawaharlal Nehru National Urban Renewal Mission (JNNURM) Overview 3, http://jnnurm.nic.in/wp-content/uploads/2011/01/UIGOverview.pdf [hereinafter JNNURM OVERVIEW 3] (projecting urban population growth); Kennedy \& Zerah, supra note 71, at 112.

75. MCKinsey Glob. Inst., URban World: MAPPing the ECONOMiC POWER OF Cities 1 (2011) (anticipating that by 2025, 136 new cities will make it on to the list of top 600 cities with the greatest effect on global growth - thirteen of these cities will be in India). 
historic milestone: more than half of the world's population now lives in cities. ${ }^{76}$ By 2050 , the global urbanization rate is expected to reach seventy percent. ${ }^{77}$ Second, cities make up an increasing proportion of total global economic output. ${ }^{78}$ For example, a 2007 McKinsey study that ranked world cities by their contribution to global growth found that while the top 100 cities produced twenty-one trillion dollars in GDP in 2007, or thirty-eight percent of the global total, they are expected to produce sixty-four trillion dollars in GDP, or nearly sixty percent of the global total, in $2025 .^{79}$ Increases in urban economic output and the growing proportion of the world's population that lives in cities highlight the need for increased attention to the role that cities play in the global economy.

India will soon have the fastest global rate of urbanization, due to a large increase in its youth population. ${ }^{80}$ Between 2014 and 2050, the number of urban dwellers in India is expected to increase by 404 million. ${ }^{81}$ Compared to other rapidly developing countries like China, India is comparatively less urbanized, but that will soon change. ${ }^{82}$ The capital of India, New Delhi, has approximately doubled its population since 1990 and became the world's second most populous city in 2014; with nearly 25 million people, it has nearly three times the population of New York City. ${ }^{83}$ Another Indian megacity, Mumbai, is within the top ten most populous cities in the world. ${ }^{84}$ As of 2011 , approximately 377 million people constituting about thirty-one percent of India's population lived in urban areas. ${ }^{85}$ With India's continued rapid urban growth, this figure is expected

76. UN DEP'T OF ECON. \& SOC. AFFAIRS, supra note 1.

77. UN-HABitat, UN-HABitat: STATE OF THE WorlD's CitiEs 2006/2007 (2007), http:// www.un habitat.org/documents/media_centre/sowcr2006/SOWCR\%205.pdf.

78. See Mohan \& Dasgupta, supra note 72, at 214 ("Urbanisation is promoted by (i) economies of scale in production particularly in manufacturing; (ii) the existence of information externalities; (iii) technology development, particularly in building and transportation technology; (iv) substitution of capital for land as made possible by technological developments.").

79. MCKINSEY GLOB. INST., supra note 75.

80. Sengupta, supra note 1.

81. UN DEP'T OF ECON. \& SOC. AFFAIRS, supra note 1 ('In 2014, the proportion of the population living in urban areas was 39 percent in lower-middle-income countries and 30 per cent in low-income countries. By 2050, these countries are expected to reach, on average, 57 and 48 percent urban, respectively.").

82. Isher Judge Ahluwalia et al., Challenges of Urbanisation in India: An Overview, in URBANISATION IN INDIA:ChALLENGES, OPPORTUNITIES AND THE WAY FORWARD, supra note 29, at 1, 2 (noting that urban populations in other countries are: " 45 per cent in China, 54 per cent in Indonesia, and 87 per cent in Brazil"); Sengupta, supra note 1.

83. Population: Current Population Estimates, DeP'T OF City Planning, N.Y.C., (2015), http:// www.nyc.gov/html/dcp/html/census/popcur.shtml (last visited Sept. 23, 2015); Sengupta, supra note 1.

84. Sengupta, supra note 1.

85. Ahluwalia et al., supra note 82 , at 2. 
to rise to about forty percent by the year $2021,{ }^{86}$ and by 2031 , to comprise around 600 million people. ${ }^{87}$

The sheer size of the urban population presents an enormous challenge where shelter, civic amenities, public health, and social security are concerned. ${ }^{88}$ In terms of population, most of the larger states in India would be among the biggest countries in the world; even a large-sized district in India would be larger than about eighty nations in terms of population. ${ }^{89} \mathrm{~A}$ huge amount of funding is required to transform urban infrastructure; investments for the period between 2011 and 2031 are estimated to be 3.9 trillion Indian rupees, which is approximately sixty-three billion U.S. dollars. $^{90}$

Despite its emerging economy, growing middle class and increasing international clout, India is also home to millions of people living in poverty. The rapid unplanned settlement of large tracts of land has led to a huge peri-urban population, which is not always counted in urban statistics. ${ }^{91}$ Historical neglect of cities has led to poor public services and housing, which have, in turn, contributed to the proliferation of slums. ${ }^{92}$ The urbanization of rural poverty as villagers move to cities in search of economic opportunity has also contributed to the expansion of slums. ${ }^{93}$ Mega-cities like Mumbai, where more than half the population live in slums, ${ }^{94}$ account for approximately fifty-six percent of the urban population; this reflects the geographic distribution of economic opportunities. $^{95}$ The state of infrastructure and civic services in India

86. See generally JNNURM OVERVIEW 3, supra note 74.

87. Ahluwalia et al., supra note 82 , at 2.

88. MOHANTY ET AL., supra note 2, at 7.

89. See GOV'T OF INDIA SECOND ADMIN. REFORMS COMM'N, supra note 2, at 21 ("[The state of] Uttar Pradesh would be larger than the world's sixth largest country.").

90. HPEC REPORT, supra note 47, at 35 (The figure in the report is listed as 39.2 lakh crores, which translates to 3.9 trillion crores).

91. GOV'T OF INDIA SECOND ADMIN. REFORMS COMM'N, supra note 2, at iv.

92. Kennedy \& Zerah, supra note 71, at 112; see also NAT'L INST. OF URBAN AFFAIRS, URBAN GOVERnANCE DECENTRALIZATION IN INDIA, at x (2004), http://www.niua.org/Publications/ research_studies/urban_governance/urban\%20governance_Summary.pdf (noting that many of the government schemes during the seventies and early eighties were targeted at just a few large cities, benefiting mostly high and middle-income communities).

93. MOHANTY ET AL., supra note 2, at 5. But see Ahluwalia et al., supra note 82, at 2 ("Ruralurban migration contributed only about 20 per cent to the growth of urban population.").

94. P.K. DAS \& Assocs., Planners \& ARChitects, Mumbai's Slums Map-2 (2011), http://www.pk das.com/published/Mumbai\%27sSlumsMap-LandReservations.pdf.

95. HPEC REPORT, supra note 47, at 18; Rao \& Bird, supra note 32, at 203. 
remains dire. ${ }^{96}$ As the former Prime Minister of India Dr. Manmohan Singh stated, "A major failure of city governance has been our inability to address the needs of the poor... Cities need people to provide services and our people need a decent place to live." ${ }^{, 97}$

\section{B. In an Important Policy Shift, India Linked Urban Renewal to Decentralization}

Over a decade after the passage of the 74th CAA, the government of India launched a national scheme designed to simultaneously promote urban renewal and decentralize power to municipalities. Created in 2005, the Jawaharlal Nehru National Urban Renewal Mission (JnNURM) sought to improve urban infrastructure and expand basic services in urban areas, including slums, through a series of local governance reforms. ${ }^{98}$ This was not the first government scheme introduced to improve urban areas. ${ }^{99}$ But the JnNURM scheme represented an important policy shift because it also sought to realize the potential of the 74th CAA by linking financial assistance for infrastructure and service delivery to the promotion of decentralization and municipal empowerment. ${ }^{100}$ Consistent with the economic and political theories of decentralization, the JnNURM scheme was grounded in idea that strengthening municipal government is the key to increased urban growth and poverty alleviation.

Although the JnNURM was not extended by Prime Minister Modi's administration, it is critical to understand the lessons of this urban decentralization experiment. The JnNURM required that target cities develop frameworks for twenty to twenty-five years, with five-year updates. ${ }^{101}$ It initially consisted of two related schemes: (1) Sub-Mission for Urban Infrastructure and Governance, which focused on water supply and sanitation, sewerage, solid waste management, road network, urban

96. MohANTY ET AL., supra note 2, at 5 ("The floods in Mumbai, Chennai, Hyderabad and Bangalore in the recent past have exposed the vulnerability of cities, their fragile ecology, weak infrastructure systems, faulty planning, long records of under-investment and fiscal imbalances.").

97. Prime Minister Manmohan Singh, Speech at the Launch of the Jawaharlal Nehru National Urban Renewal Mission, (Dec. 3, 2005), pib.nic.in/newsite/erelcontent.aspx?relid=13823.

98. Ahluwalia et al., supra note 82 , at 45-47; HPEC REPORT, supra note 47, at 29; see generally SIVARAMAKRISHNAN, supra note 37 (comprehensively discussing the JnNURM).

99. See generally SIVARAMAKRISHNAN, supra note 37, at 2-12 (discussing prior policy efforts); Savage \& Dasgupta, supra note 24, at 46-47 (providing summary of key Government of India policies designed to improve the quality of life in urban areas).

100. Gov't of India SECOND ADMIN. ReFORMS COMM'N, supra note 2, at 22-26; Kennedy \& Zerah, supra note 71, at 112-13; Savage \& Dasgupta, supra note 24, at 56 (noting that the JnNURM represents a "significant shift in public policy" by focusing more on accountability).

101. See SIVARAMAKRISHNAN, supra note 37 , at 17-46 (providing an overview of the JnNURM scheme and its components). 
transport, and redevelopment of old city areas and was managed by the Ministry of Urban Development; and (2) Sub-Mission for Basic Services to the Urban Poor (BSUP), which emphasized integrated development of slums, including projects for providing shelter, basic services, and other related civic amenities and was administered by the Ministry of Urban Employment and Poverty Alleviation. ${ }^{102}$ These two programs targeted sixty-five cities of national importance. ${ }^{103}$ In addition, two programs were created under JnNURM for other cities and towns: Urban Infrastructure Development Scheme for Small and Medium Towns (UIDSSMT) and Integrated Housing \& Slum Development Program (IHSDP). ${ }^{104}$ While UIG and UIDSSMAT are city-wide infrastructure-oriented programs, BSUP and ISHDP are directed towards creating housing and basic amenities for the urban poor, especially slum-dwellers. ${ }^{105}$

The JnNURM also sought to promote grassroots democracy through citizen-oriented municipal reforms. Participating cities were expected to formulate City Development Plans that identified appropriate projects. For each project, the city or appropriate parastatal agency-usually a semiautonomous public corporation-prepared a Detailed Project Report identifying the life-cycle costs of the project, including capital outlays, operations, and maintenance. Once approved, the funds flowed from the central government to the state government and, finally, to the designated "State Level Nodal Agency," which disbursed them. Most importantly for the purposes of this article, the JnNURM not only linked infrastructure financing to governance reforms at the state and local levels, but looked to the 74th CAA and community participation as vehicles for achieving reform. ${ }^{106}$

102. JNNURM OVERVIEW 3, supra note 74, at 5-6.

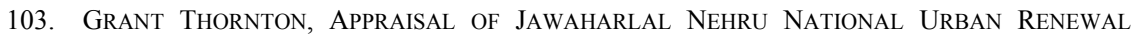
MISSION (JNNURM) 253 (2011), http://jnnurm.nic.in/wp-content/uploads/2012/06/Appraisal-ofJnNURM-Final-Report-Volume-I-.pdf; MINISTRY OF HOUS. \& URBAN POVERTY ALLEVIATION, GOV'T OF INDIA, OVER All Progress OF JNNURM UNDER BSUP AND IHSDP- NATIONAL LEVEL (2015), http://ipomstest.cgg.gov.in/jnnurm/Jnnurm_Ray_AHP_Progress_Report/Jnnurm_Glance_All_Progress. pdf (noting that as of January 2015, 481 BSUP projects in 62 cities/towns and 1,037 IHSDP projects in 887 cities/towns were implemented for a total project cost of 31,732.77 crore's of rupees); PLANNING COMM'N, GOV'T OF INDIA, TwELFTH FIVE YEAR PLAN (2012-2017): ECONOMIC SECTORS - VOLUME II, at 1, 353 (2013), http://planning commission.nic.in/plans/planrel/12thplan/pdf/vol_2.pdf [hereinafter TwelfTh Five Year Plan - VOlume II].

104. THORNTON, supra note 103.

105. See id. (introducing the JnNURM mission).

106. Kennedy \& Zerah, supra note 71 , at 113 ("These reforms aim to alter rules and regulations relating to urban development by clarifying institutional responsibilities, repealing land regulations, modernising the functioning of municipalities, enhancing their revenues and fiscal responsibility, among other things."). 
The JnNURM led to increased investment in urban areas, though there were significant implementation challenges. ${ }^{107}$ The central government's initial outlay of approximately 661 billion rupees (10.7 billion U.S. dollars) resulted in an overall commitment of approximately 1.237 trillion rupees (20 billion U.S. dollars) during the first seven years (2005-2012) ${ }^{108}$ While the scheme officially ended in 2012, it was extended for another two years until 2014. ${ }^{109}$ The Congress-led government of Manmohan Singh had been planning to launch a second phase of JnNURM, which was to dispense with the concept of "mission cities" and, instead, cover all towns and cities. ${ }^{110}$ The government had also proposed other revisions to streamline the scheme and reduce overlap with other national programs. ${ }^{111}$

But recently elected Prime Minister Narendra Modi replaced the JnNURM with his own urban renewal scheme, known as the Atal Mission for Rejuvenation and Urban Transformation (AMRUT). ${ }^{112}$ The AMRUT

107. See Smriti Kak Ramachandran, Urban Renewal Mission a Failure: CAG, HINDU (Dec. 1, 2012), http:/www.thehindu.com/todays-paper/tp-national/urban-renewal-mission-a-failure-cag/article 4152567.ece (describing implementation challenges).

108. TwELFTH FIVE YEAR PlAN - VOLUME II, supra note 103, at 322 (as reported, the initial outlay was 66,085 crore and the overall commitment was 123,711 crore; one crore is equal to 10 million); Isher Judge Ahluwalia, Urban Infrastructure and Service Delivery, in URBANISATION IN INDIA: CHALLENGES, OPPORTUNITIES AND THE WAY FORWARD, supra note 29, at 31, 46 ("The Government of India committed 66,000 [rupees] crore over the Mission period of seven years (extended later to nine) as its share in the total investment of over 100,000 [rupees] crore for a pool of selected projects to be proposed by the ULBs and state governments and approved by the Government of India.").

109. Deepak Nagpal, Narendra Modi Government to Drop Jawaharlal Nehru's Name from JNNURM?, ZEE NEWS (Aug.12, 2014), http://zeenews.india.com/news/nation/narendra-modigovernment-to-drop-jawaharlal-nehru-s-name-from-jnnurm_954093.html.

110. TWELfTH Five Year Plan - Volume II, supra note 103, at 353. But see generally SAMA Khan, The OTHER JNNURM: What DOES IT MEAN FOR SMALl TOWNS IN INDia? (2014), http://cpr india.org/sites/default/files/The\%20Other\%20JNNURM.pdf (discussing bias against small towns).

111. The JnNURM II was to have these components: (1) Urban Infrastructure and Governance (UIG); (2) Rajiv Awas Yojana (RAY); (3) Slum rehabilitation in cities not covered under RAY; and (4) a separate fund dedicated to Capacity Building. Under the five-year budget for the JnNURM set forth in Twelfth Five Year Plan, the first three programs would receive 80 percent of the funding; the Capacity Building program would receive 10 percent; and an additional Incentive Fund would receive the final 10 percent. See Ministry of Hous. \& Urban Poverty Alleviation, Gov't of India, Office MEMORANDUM: EXTENSION OF TIME PERIOD BY ONE YEAR UP TO 2014-15 FOR COMPLETION OF PROJECTS SANCTIONED TILl MARCH 2012 AND IMPLEMENTATION OF REFORMS UNDER THE SuBMission on BASIC SERVICES to THE Urban PoOR (BSUP) AND INTEGRATED Housing AND SLUM DEVELOPMENT PROGRAMME (IHSDP) - COMPONENTS OF THE JAWAHARLAL NEHRU NATIONAL URBAN RENEWAL MISSION (JNNURM) (2013), https://jnnurmmis.nic.in/jn nurm_hupa/jnnurm/jnnurm Extension_2014-15_19_09_2013.pdf (noting that BSUP and IHSDP programs would be discontinued but be given an additional extension until March 2015 to complete existing projects); TWELFTH FIVE YEAR PLAN - VOLUME II, supra note 103, at 338-39, 353-54 (noting that the slum rehabilitation scheme known as Rajiv Awas Yojana would be integrated into the JnNURM-II).

112. PM's Remarks, supra note 9. 
has a wider geographic scope than the JnNURM, focusing on 500 cities $^{113}$ as opposed to sixty-five. ${ }^{114}$ Despite their differences, the JnNURM and the AMRUT have a critical similarity. By providing greater funds to those states that devolve power down to the municipal level, both encourage decentralization using the promise of urban renewal funds. ${ }^{115}$ Among other programs, "116 Modi has also created a "Smart Cities" program"17 and a "Housing for All" campaign that aims to make affordable housing available for all by $2022 .{ }^{118}$

As India prepares to enter a new phase of urban renewal under Prime Minister Modi, the time is ripe for reflecting on the successes and failures of the JnNURM. The government of India has acknowledged many of the JnNURM's shortcomings, including variable results across the country; lack of capacity at the local level to implement reforms; incomplete governance and financial reforms; an inability to leverage additional financial resources from the private sector via public-private partnerships; and the dominant role of the central government. ${ }^{119}$ Despite programs

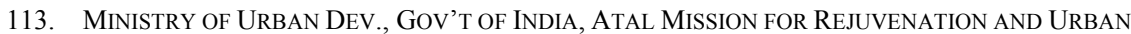
TRANSFORMATION: MISSION STATEMENT AND GUIDELINES 6 (2015), http://amrut.gov.in/ writereaddata/ AMRUT\%20Guidelines\%20.pdf [hereinafter ATAL Mission].

114. See generally Amitabh Kundu, India's Sluggish Urbanisation and its Exclusionary Development, in URBAN GROWTH IN EMERGING ECONOMIES: LESSONS FROM THE BRICS 191, 191232 (2014) (analyzing India's urban growth in contrast with other countries); ATAL MISSION, supra note 113 (drawing attention to the scheme's emphasis on cities with 100,000 people or more and its strong focus on improving the water supply, sewerage and septage management, storm water drainage, urban transport and the development of green spaces and parks).

115. ATAL Mission, supra note 113, at 8-9. The way in which the JnNURM and the AMRUT tie funding to reform adoption is different. The JnNURM employs a more punitive model—states that are found not complying with the plan's timeline for the devolution of powers are denied funds that they would have otherwise been able to access. In contrast, AMRUT employs an incentive based model in which states that are found in compliance are given additional funds. A full ten percent of AMRUT's initial plan outlay has been earmarked for these incentive payments. Id.

116. See, e.g., PM Modi's Digital India Campaign All Set to Roll Out Next Month, INDIA TODAY (Oct. 2, 2014), http://indiatoday.intoday.in/story/pm-modis-digital-india-campaign-all-set-to-roll-outnext-month/1/393789.html (noting that in the first stage of this campaign, the central government hopes to provide free $\mathrm{Wi}-\mathrm{Fi}$ to 2,500 cities in towns and that campaign is believed to take at least three years).

117. But see Persis Taraporevala, Creating Subjects in Lavasa: The Private City, OPEN SECURITY (Apr. 16, 2013), https://www.opendemocracy.net/opensecurity/persis-taraporevala/creating-subjects-inlavasa-private-city (outlining concerns about a trend in India towards the creation of cities that are governed by corporations that have no democratic governance structure).

118. PM Narendra Modi Reviews Preparations for "Housing for All” Project, ECON. TiMES (Jan. 21, 2015), http://articles.economictimes.indiatimes.com/2015-01-21/news/58306298_1_ program meprime-minister-narendra-modi-national-housing-bank.

119. See HPEC REPORT, supra note 47, at 33 (drawing attention also to the lack of clarity in the reforms and the unwillingness of state governments to devolve power down to local governments); Ahluwalia, supra note 108, at 50-52; TWELFTH FIVE YEAR PLAN - VOLUME II, supra note 103, at 323. 
intended to provide basic services to the urban poor, this goal has remained largely unmet. ${ }^{120}$ The Comptroller and Auditor General (CAG) of India also found that the JnNURM's attempt to strengthen urban local bodies was unsuccessful. The CAG noted that:

Other than execution of housing and urban infrastructure, it [the JnNURM] was also intended to strengthen the urban local bodies (ULBs) in terms of their structure, composition, financial resources, functions and powers.... However in the selected States/UTs [Union Territories], we observed that all the mandatory and optional reforms were not implemented as per the commitments made in the Memorandum of Agreement. Thus the objective of bringing about reforms in institutional, financial and structural governance structure of the ULBs to make them efficient, accountable and transparent could not be achieved as has been envisaged. ${ }^{121}$

This article argues that the JnNURM did not achieve its ultimate goals in large part because of larger constitutional challenges to decentralization that persist today.

\section{IMPEDIMENTS TO DECENTRALIZATION OF POWER TO CITIES}

The structure of India's Constitution both promotes and impedes the processes of decentralization and municipal empowerment. Political decentralization has proven difficult because states can-but are not required to - devolve power to municipalities under the 74th CAA. As a result, states have not given as much authority to municipalities as the drafters of the $74^{\text {th }}$ CAA originally contemplated. India's efforts at administrative decentralization have been hindered by the municipalities' lack of capacity and technical expertise, as well as competition with entrenched parastatal agencies. Those barriers, in turn, have reduced the states' incentives to devolve power to municipalities. Fiscal decentralization has not occurred because financial responsibility, but not revenue, has been devolved to municipalities. Although the JnNURM harnessed national funds for urban renewal, these funds were channeled through the states and, therefore, the outlays did not result in a transformation of the fiscal federal system. The challenges to India's

120. See Kennedy \& Zerah, supra note 71, at 113 (noting the lack of attention to the poor "despite a sub-mission dedicated to basic services of the urban poor" (internal parentheses omitted)).

121. Ramachandran, supra note 107. 
political, administrative, and fiscal decentralization efforts are explored in the sub-sections that follow. ${ }^{122}$

\section{A. Political Decentralization}

The comparatively recent focus on empowering India's cities is in stark contrast with India's history as a highly centralized federal system. As argued below, this history is critical to understanding the challenges to effectively decentralizing power to municipalities in India. Although the 74th CAA constitutionally recognized municipalities, it did not confer independent political power to them. Rather, municipalities derive their authority from the states - and the states must enact legislation to devolve power to the municipalities. States were likely reluctant to decentralize power to local bodies because of the states' historically weak position visà-vis the national government.

\section{States in India Have Historically Been Weak Vis-à-Vis the Central Government \\ When India achieved independence from the British in 1947, the drafters of the Indian Constitution believed that federalism could address the need for political stability and help to transform the economy. ${ }^{123}$ Given India's diverse population and geographically concentrated minorities, federalism's potential to mitigate intrastate conflict made it particularly attractive. ${ }^{124}$ Even prior to independence, India was moving in the direction of federalism. ${ }^{125}$ The then-Princely States called for federalism in reaction}

122. Political scientists Aaron Schneider and Daniel Treisman each establish a helpful framework for conceptualizing decentralization. See Aaron Schneider, Decentralization: Conceptualization and Measurement, 38 STUD. COMP. INT'L DEV. 32, 32-56 (2003) (defining decentralization through three core dimensions: fiscal, administrative, and political); Daniel Treisman, Defining and Measuring Decentralization: A Global Perspective (March 2002) (unpublished manuscript), http://www.ssc net.ucla.edu/polisci/faculty/treisman/Papers/defin.pdf (dividing decentra-lization into a number of different forms that are subsumed here into the term "political decentralization).

123. See generally RATH, supra note 12, at 34-35 (noting that the drafters hoped federalism would reconcile conflicting groups in India and that although India adopted a federal system, "the word 'federation' or 'federal' occurs nowhere in the Constitution").

124. See id. at 31-34 (noting that the Muslim community also believed that their rights would be better protected under a federal government than under a unitary government); see also Nancy Bermeo, A New Look at Federalism: The Import of Institutions, 13 J. DEMOCRACY 96, 97 (2002), http:// www.hks.harvard.edu/fs/pnorris/Acrobat/stm103\%20articles/bermeo_Federalism_conflict.pdf (finding that rather than increasing ethnic conflict, federal systems may play a key role in helping ethnic groups achieve peaceful political accommodation).

125. See Round Table Conference, ENCYCLOPÆDIA BRITANNICA, http://www.britannica.com/ EBchecked/topic/510855/Round-Table-Conference (last visited Sept. 22, 2015) (noting that the possibility of making India's government a federal system was discussed at the Round Table 
to British rule. They perceived the British as having encroached upon their power and were worried about the possibility that the central government of India might one day be able to do the same. ${ }^{126}$

Although India's national government is a de jure union government, it is often considered to be a de facto central government because of the strength of the national government compared to the state governments. ${ }^{127}$ Despite its linguistic, religious, and ethnic diversity, India is also comparatively more centralized than other federal countries. ${ }^{128}$ India can be described as a holding together federation; in contrast, the United States is a coming together federation comprised of states that were autonomous before uniting. ${ }^{129}$ While the decision to use the word "[u]nion" or "central" to describe India's national government may reflect user bias, ${ }^{130}$ the terms "central government" or "the Center" are used throughout this article because they are used in many national government reports. ${ }^{131}$

Several factors have contributed to the centralization of power in India. India was founded as a "sovereign socialist... democratic republic," 132 and, as a result, the central government played a strong role in economic development during India's first few decades as an independent

Conferences of 1930-32 and that these conferences then led to the development of the 1935 Government of India Act, which did in fact establish a federal system that was never used in practice).

126. See RATH, supra note 12, at 31 (noting how the Princes viewed federalism was a way "to strengthen their position and secure some power in determining all-Indian policies").

127. Chaubey, Federalism in India, supra note 16, at 1, 3, 5; see also RATH, supra note 12, at 18 (noting that the Indian system is "unitary" and "effective").

128. See Shrawan K. Singh, Federal Transfers in India: An Introduction, in FisCAL FEDERALISM IN INDIA, supra note 15, at 11, 14; See RATH, supra note 12, at 19 (noting that India is an asymmetric federation, where linguistic, religious or linguistic cleavages can "coincid[e] with the sub-national units").

129. See RATH, supra note 12, at 55 (noting that India's federalism and parliamentary system can work against each other); Douglas V. Verney, Federalism, Federative Systems, and Federations: The United States, Canada, and India, 25 PuBlius 81, 81, 83 (1995) (noting that the term "federalism" was first articulated by the framers of the U.S. Constitution, and that federalism in India combines some of these American ideals with the British parliamentary tradition).

130. See Chaubey, Union-State Fiscal Relations, supra note 15, at 44, n.1, 2 (arguing that referring to the national government as the "Center" is extra-constitutional, if not unconstitutional, and also noting that the term "state" in the Constitution has different meanings because it is used to refer to the union government, the state governments, and also more generally to public entities).

131. See, e.g., B.K. Chaturvedi, Report of the CommitteE ON Restructuring OF Centrally SPONSORED SCHEMES (CSS) 24 (2011), http://planningcommission.nic.in/reports/genrep/ css/rep_css1710.pdf (noting that the JnNURM was a so-called "centrally sponsored scheme"); Ministry of Fin., AN ECONOMIC AND FUnCTIONAL ClASSIFICATION OF THE CENTRAL GOVERNMENT BUDGET (2006-2007), http://finmin.nic.in/reports/FunClass200607.pdf; MINISTRY OF FIN., REPORT OF THE COMmittee for Evolving a COMPosite Development IndeX of StATeS (2013), http://fin min.nic.in/reports/Report CompDevState.pdf.

132. INDIA CONST. pmbl. 
country. ${ }^{133}$ The Constitution also gives the central government broad authority compared to the states. For example, while a Proclamation of Emergency is in effect, Article 250 allows the central legislature to make laws with respect to matters in the State List. ${ }^{134}$ In addition, Article 353(b) gives the central government the power to create laws on issues not explicitly in the Union list. ${ }^{135}$ During an emergency, Article 354 gives the president the power to suspend provisions relating to the transfer of revenue from the Center to the states. ${ }^{136}$

The 1960s and 1970s, in particular, witnessed a strong consolidation of power at the Center. ${ }^{137}$ Under Indira's Gandhi initial term (1966-1977), the Indian National Congress required Congress-led states to choose party nominees for the position of State Chief Minister, and the central government also committed itself to working to destabilize oppositioncontrolled state governments. ${ }^{138}$ In addition, Gandhi frequently invoked Article 356 of the Constitution, which allows the central government to take over the state when the state government is not "in accordance with the provisions of this Constitution." 139 The central government further strengthened its power during the State of Emergency declared between 1975 and $1977 .{ }^{140}$

133. T.V. Sathyamurthy, Impact of Centre-State Relations on Indian Politics: An Interpretative Reckoning, 1947-87, 24 ECON. \& POL. WKLY. 2133, 2135-36 (1989). In the 1960s, the Indian government became even more centralized as it tried to deal with the mass unrest that resulted from increasing dissatisfaction with what had previously been the ruling party, the Congress Party. Id. It was during this time that the Congress Party began to require Congress-led states to choose one of the party's nominees for the position of Chief Minister. Id. At this time, the Centre also committed itself to working to destabilize opposition-control state governments. Id.; see also RATH, supra note 12, at 50 (" $[\mathrm{P}]$ oints of dispute [between the Centre and the States] began to raise their heads from the time of the formulation of the Third Five-Year plan. They assumed greater magnitude as a result of the political developments after 1964 - after the death of Nehru, the economic difficulties of 1965 and 1966, the interruption in planning, and the changing political situation, especially after the General Election in 1967.").

134. INDIA CONST. art. 250.

135. INDIA CONST. art. 353(b).

136. M. GOVInda RaO \& NiRViKar Singh, POLITICAL ECONOMY OF FEDERALISM IN INDia 49 (2005).

137. G. RAdHAKRISHNA KuRUP, POLITICS OF CONGRESS FACTIONALISM IN KERALA SinCE 1982, at 49, 52-53, 75 (2004). Indira Gandhi has been credited both for the split of the Congress Party in 1966 and the creation of the Janata Party. Gandhi contributed to the split of the Congress Party by choosing her own candidate for President instead of the party nominated one. The Janata Party was later formed by individuals who were outraged by the excessive centralization of Gandhi's rule. Id.

138. Sathyamurthy, supra note 133 , at 2136.

139. See INDIA CONST. art. 356 (outlining "provisions in case of failure of constitutional machinery in States").

140. See, e.g., Violation OF DEMOCRATIC RightS IN INDIA 196-98, 201 (A.R. Desai ed., 1986) (noting that the central government further strengthened its power by making a number of changes to 
Although Gandhi's Congress Party was replaced by the opposition Janata Party in 1977, the trend towards centralization continued - and was even exacerbated. ${ }^{141}$ While the central government had previously taken over states by declaring "President's Rule," the Janata government went further, seeking to dissolve all the state assemblies at once. ${ }^{142}$ The central government had so much power that it was referred to as a unique "hybrid of a federal and unitary constitutional structure" 143 or "quasi-federal."." As these political dynamics illustrate, "the federal process is very difficult to achieve in countries where the federal principle is combined with a parliamentary system of government for it is generally accepted that the two systems work almost in opposite directions-federalism tends to diffuse power whereas a parliamentary system tends to concentrate power." 145

This excessive centralization was met with growing calls for greater state autonomy and even secession. ${ }^{146}$ As a result, several commissions were constituted to study center-state relations, but it is not clear whether they have had any substantive impact. For example, a committee was constituted in 1969 during Gandhi's first term to study state autonomy and center-state relations under the chairmanship of P.V. Rajmannar, but the ultimate recommendations were ignored by the Center. ${ }^{147}$ In 1984, Gandhi,

the Maintenance of Internal Security Act (MISA), which involved progressively stripping political prisoners and other detainees of their rights); UJJWAL KUMAR SiNGH, THE STATE, DEMOCRACY AND ANTI-TERROR LAWS IN INDIA 65 (2007) (discussing how the National Emergency of 1975 allowed MISA to assume "formidable proportions").

141. See RATH, supra note 12, at 75-76 (noting how the Center proposed dissolution of several State Assemblies in 1977).

142. Id. at 76; see also Mikhail Filippov et Al., Designing Federalism: A TheOry of SelfSUSTAINABLE FEDERAL INSTITUTIONS 214 n.28 (2004) (noting that India's federalism is not "market preserving" due to a lack of "credible commitment to limiting the role of the center in economic regulation").

143. Vasuki Nesiah, Federalism and Diversity in India, in AUTONOMY AND ETHNICITY: Negotiating Competing Claims in Multi-EThnic States 53, 54 (Yash Ghai ed., 2000).

144. Aiyar, supra note 5, at 115. But see Ramachandran, supra note 5, at 58 (taking issue with the use of the term "quasi-federal" on the basis that it suggests that the Indian system is based on an underlying idea that is "not federal," which he does not believe is the case).

145. Rath, supra note 12, at 55.

146. See id. at 72 ("The States demanded more autonomy by flaunting threats of secession."); B.D. DuA, The Prime Minister and the Federal System in INDIA, IN INDIAN FEDERALiSM IN the NeW MiLlENNIUM 131 (2003).

147. RATH, supra note 12, at 39-40 (noting that the committee, which was constituted in 1969, recommended the omission of Articles 256, 257, and 339(2) of India's constitution, which would have significantly reduced the control over the States by the Union and increased state autonomy); Indira Ghandi: Prime Minister of India, ENCYCLOPÆDIA BRITANNICA, http://www.britannica.com/biography/ Indira-Gandhi (last visited Sept. 24, 2015) (stating that Indira Gandhi initially became Prime Minister in 1966 , leaving that office in 1977). 
in her second term as Prime Minister, commissioned Supreme Court Justice Rajinder Sarkaria to lead a committee examining the state of center-state relations. Yet despite its length, the final report produced by the Sarkaria Commission suggested little in the way of structural reform. ${ }^{148}$ Instead, it focused more on the stabilization of center-state relations. Some believed the Sarkaria Commission to be a political maneuver by Indira Gandhi so she could seem to be responding to the concerns of regional actors. ${ }^{149}$ The Sarkaria Commission's ultimate lack of "claws" also demonstrated the difficulty of translating political will alone into meaningful change.

While the Sarkaria Commission focused on the stabilization of centerstate relations, it also made several recommendations that would have strengthened the position of the states vis-à-vis the central government. This specific subset of recommendations attempted to confer more power on the states and state leaders and to protect the states from negative interference by the central government. For example, the Commission recommended that all residual powers, except those related to taxation, go to the Concurrent List. ${ }^{150}$ The Commission also tried to protect the state governments from central interference by prescribing restraint in the central government's use of Article 356 of the Constitution. ${ }^{151}$ Finally, the Commission tried to limit gubernatorial manipulation by the Center by recommending that state governors not come from the Center's ruling party. ${ }^{152}$ While, as a whole, the Sarkaria Commission's recommendations served to reinforce the status-quo in center-state relations, there was a specific group of provisions that-if implemented-could have greatly strengthened the position of the states.

Although few of the Sarkaria Commission's recommendations were implemented, the late 1980s saw a major breakthrough in the movement towards greater decentralization. ${ }^{153}$ In 1989, for the first time, the Indian Parliament reviewed a set of legislative bills, known as the 64th and 65th Amendments, designed to give the panchayats and municipalities constitutional status. At that time, then Prime Minister Rajiv Gandhi was likely looking to check the power of state leaders as the Congress Party had

148. Amal Ray, The Sarkaria Commission's Perspective: An Appraisal, 23 ECON. \& POL. WKLy. 1131, 1131 (1988).

149. Lawrence Saez, The Sarkaria Commission and India's Struggle for Federalism, 8 CONTEMP. S. ASIA 41, 42 (1999).

150. SARKARIA COMMISSION REPORT $\uparrow \uparrow$ 2.4.03, 2.6.16 (1988), http://www.gangothri.org/node/74.

151. Id. $₫ 3.5 .23$.

152. See id. $\llbracket 4.6 .09$ (stating that the governor should be from "outside the State").

153. See generally SIVARAMAKRISHNAN, supra note 24 (describing the dynamics of decentralization in India over numerous decades). 
just lost control in a number of states. ${ }^{154}$ This was also a time when the unity of the Indian state was being questioned. As separatists in central India and Uttar Pradesh gained strength, it became clear that some power needed to be devolved to keep the union intact. ${ }^{155}$ "[A]s the states gained more bargaining power in the $1980 \mathrm{~s}$, the Center may have looked to stronger local governments as a counterweight." ${ }^{156}$ Gandhi's political inexperience combined with the political exigencies of the time allowed him to take a fairly radical step forward towards local democracy. ${ }^{157}$

While the 64th and 65th Amendments failed in the Rajya Sabha, movement towards greater decentralization continued in the 1990s. In 1990, the Sarkaria Commission's recommendation for the creation of an Inter-State Council (ISC) was implemented. ${ }^{158}$ The ISC was charged with reviewing the other recommendations of the Sarkaria Commission. ${ }^{159}$ In particular, the Council accepted the Sarkaria Commission's recommendation that when making legislation on items in the Concurrent List, the central government should consult with the state governments. ${ }^{160}$ While little attention was given to the Sarkaria Commission recommendations in the first two years after they were issued, the creation of the ISC represented a positive step forward. The creation of the ISC was important not only because it meant that one of the Commission's recommendations was being realized, but also because it provided a forum for continuing debate on the rest of the recommendations made by the Sarkaria Commission.

154. D. Bandyopadhyay et al., Dependency vs Autonomy: The Identity Crisis of India's Panchayats, in Grass-RoOTS DEMOCRACY IN INDIA AND ChINA: THE Right To PARTICIPATE 53, 63 (Manoranjan Mohanty et al. eds., 2007).

155. Bandyopadhyay et al., supra note 154 , at 63.

156. RAO \& SINGH, supra note 136 , at 61 ; see also CRISPIN BATES \& SUBHO BASU, RETHINKING INDIAN POLITICAL INSTITUTIONS 186-89 (2005) (noting that the next major piece of legislation that focused on local government was the 64th Constitutional Amendment, but the bill ironically did not pass because it was perceived as a ploy by the Indian National Congress to expand the role of the Center); B.K. Chandrashekar, Panchayati Raj Bill: The Real Flaw, 24 ECON. \& POL. WKLY. 1433, 1433 (1989) (drawing attention to the 1978 Asok Mehta report, which stated that panchayati raj institutions should be established, and that they "could be empowered by the state legislature with executive and administrative functions").

157. Bandyopadhyay et al., supra note 154 , at 62 .

158. HAMID HuSSAIN, INDIAN FEDERALISM: EMERGING TRENDS 28-30 (2010).

159. Lawrence Sáez, Federalism without a Centre: The Impact of Political and ECONOMIC REFORM ON INDIA'S FEDERAL SYSTEM 126-27 (2002) (noting that between 1991 and 1993 the ISC developed recommendations related to 179 of the Sarkaria Commissions 247 proposals, and that the ISC recommended implementing 130 of the Commission's recommendations as they were originally written, slightly modifying twenty-five of these recommendations, and not implementing twenty-four of the Commission's recommendations).

160. Id. at 127 . 
In 1992, with the passage of the 73rd and 74th Constitutional Amendment Acts, panchayats and municipalities were given constitutional status for the first time in India's history. The draft version of these two amendments came out of an extended discussion led by then Prime Minister V. P. Singh at the June Conference of Chief Ministers. ${ }^{161}$ The 73rd and 74th Amendments were structured in a very similar manner to the proposed 64th and 65th Amendments. The 73rd Amendment, like the 64th Amendment, focused on the devolution of power down to the panchayats while the 74th Amendment, like the 65th Amendment, pertained to the devolution of power down to urban local bodies. The main difference between them is that the 73rd and 74th Amendments devolved more power to the states. The writers of the 73rd and 74th Amendments appeared cognizant of the fact that one of the main reasons the 64th and 65th Amendments were defeated is that they were seen as a ploy by the Center to bypass the states. Motivated by this concern, the authors of the 73rd and 74th Amendments took pains to identify areas where power could remain with the states and areas where the panchayats and municipalities could be empowered to function as units of self-government. ${ }^{162}$ This work paid off and the 73rd and 74th CAAs were passed. After a decades-long push for greater political decentralization, India had finally created a constitutionally enshrined third tier of government. ${ }^{163}$

However, the 73rd and 74th Amendments were not without weaknesses. While Article 243Q of the Constitution states that municipalities should be created in every state, it is followed by a proviso stating that municipalities do not have to be created in urban areas designated as industrial townships. ${ }^{164}$ Critics claim that this proviso goes against the basic spirit of the 74th Amendment, ${ }^{165}$ and as the number of industrial townships or Special Economic Zones has grown since 2005, this proviso has gained greater salience.

161. Shriram Maheshwari, The Indian Administrative Year BooK: 1990, at 222 (1990). A fierce debate occurred at the June Conference of Chief Ministers over the devolution of power. There were two subjects in particular on which the ministers present at this conference did not agree. The first was the role that State Finance Commissions should play in monitoring local financing. The second was how general elections should be held. Id.

162. See generally Sweta Mishra, Democratic Decentralisation in India: Study in RETROSPECT \& PROSPECT 82-97 (1994).

163. See id. (noting that one of the main differences between these two bills is that a number of the different powers that were to be assigned to the Center in the 64th and 65th amendment would now be assigned to the state legislatures).

164. INDIA CONST. art. 243Q.

165. K.C. Sivaramakrishnan, The Devolution Deficit, INDIAN EXPRESS (May 1, 2013), http:// archive.indianexpress.com/news/the-devolution-deficit/1109816/. 
After the passage of the 73rd and 74th CAAs, several factors led to an improvement in the position of the states vis-à-vis the central government. ${ }^{166}$ Thanks to economic liberalization, state-level regulation assumed new importance as pressure mounted for less regulation at the national level. The 1990s also saw new coalitions form between national and regional parties as national parties struggled to win an outright majority in the national polls. ${ }^{167}$ Because many leaders of regional parties were also state leaders, this development indirectly increased the power of the states. The last factor that contributed to the growing influence of the states post1992 is the S.R. Bommai v. Union of India ruling of $1994 .{ }^{168}$ In this seminal case, the Supreme Court placed limitations on the President's ability to use Article 356 of the Indian Constitution to dismiss state governments. ${ }^{169}$ As a result of these key economic, political, and legal developments, the power of the states increased in the 1990s, which limited the centralizing tendencies in India to a degree. ${ }^{170}$ However, even with these reforms, India is still a highly centralized federal country.

The recent election calls into question the trend toward state-oriented power. In May 2014, the BJP, a national party, won the highest number of seats by a single party in what is now being described as the "post-regional politics era." ${ }^{171}$ With 282 out of 543 seats, the BJP successfully formed a government without a coalition, "a feat that no party has come close to

166. Gov'T OF India SECOND AdMin. ReForms COMM'N, supra note 2, at 13 (noting that states were devolved greater power due to the "rise of regional parties and coalition governments at the State and Union levels, greater economic liberalisation reducing State control and diminishing the importance of State investment in commercial undertakings, a very healthy tradition of fair non-discriminatory fiscal devolution through various mechanisms and compulsions of economic growth engendering a healthy competition for investment"); see also Aseema Sinha, The Changing Political Economy of Federalism in India: A Historical Institutionalist Approach, 3 INDIA REV. 25, 26 (2004) (explaining that the nature of competition for states in India transitioned from vertical competition (for resources from the Center) to horizontal competition (states competing with each other)).

167. See Milan Vaishnav, The Complicated Rise of India's Regional Parties, CARNEGIE ENDOWMENT FOR INT'L PEACE, (Nov. 13, 2013), http://carnegieendowment.org/2013/11/13/ complicated-rise-of-india-s-regional-parties/gtph (indicating that due to the rise of regional parties, it has become unimaginable for one single party to control the Indian government).

168. See generally S.R. Bommai v. Union of India, (1994) 2 S.C.R. 644 (India).

169. M.P. Singh, Towards a More Federalized Parliamentary System in India: Explaining Functional Change, 74 PAC. AFF. 553, 565-66, 558 (2001). The case arose because in 1991, the then Governor of Tamil Nadu refused to officially recommend the dismissal of his government when asked to do so by the central government. Historically, when the central government indicated that a governor needed to recommend the dismissal of their government the governors did so without question because of their close ties to the central government. Id.

170. See HuSSAIN, supra note 158, at 81-91 (noting an era of coalition governments after 1989 that often contained regional parties).

171. S. Rukmini, How the BJP Won this Election, HINDU (May 18, 2014), http://www.the hindu.com/news/national/how-the-bjp-won-this-election/article6020712.ece. 
since the 1984 election which saw a wave of sympathy following the assassination of Congress Prime Minister Indira Gandhi."172 Indeed, this is the first time in Indian history that any single party secured more votes than the Congress Party. ${ }^{173}$ Although the new Prime Minister, Narendra Modi, rose to power as the leader of the state of Gujarat, he has an "authoritarian" leadership style because "[b]y instinct [he] centralises power.", A spowerful Prime Minister's office could make it difficult for Modi to provide a greater role for states in policymaking. ${ }^{175}$

\section{Cities Derive Their Power from the State}

India's history as a highly centralized country and the ongoing struggle by states for greater power provides important context for understanding the challenges to municipal decentralization in India. After the passage of the 74th Constitutional Amendment, the transfer of power and funds to municipalities has been nominal in most states. ${ }^{176}$ Significant variation exists in the extent to which states have devolved authority to municipalities. ${ }^{177}$ This reflects one of the challenges of decentralization in a federal country where the central government does not have a direct relationship with the municipal level. Instead, the local government is completely under the authority of the state government. ${ }^{178}$ Uniformity of

172. Id. But see Adam Ziegfeld, India's Election Isn't as Historic as People Think, WASH. Post (May 16, 2014), http://www.washingtonpost.com/blogs/monkey-cage/wp/2014/05/16/indias-electionisnt-as-historic-as-people-think/. While described as a political landslide, the BJP in fact only gained approximately $31 \%$ of the vote. Like the U.S., India has a single-member district (SMD) electoral system, which means that votes do not necessarily translate proportionally into seats. Id.

173. See Narendra Modi, Promising the Good Times, ECONOMIST (May 24, 2014), http://www.economist.com/news/briefing/21602710-overwhelming-election-victory-promises-reshapeindian-politics-promising-good-times ("Mr Modi's victory has disproved an article of political faith from the past three decades: that India's messy democracy, cursed by strong regional and caste-based parties, could produce only fragmented outcomes and weak coalition governments. This, the clearest result since 1984, should mean stable, decisive and predictable rule. Mr Modi, not one to hold back, hints at being in office for a decade or more.").

174. Id.

175. See Ziegfeld, supra note 172 ("Moving forward, the implications of this election for policy may be profound. A return to single-party majority government for the first time in 25 years and a BJPled government unfettered by the demands of coalition partners may well produce policy changes unlike anything we have seen before in India."); Vaishnav, supra note 167 (identifying trends that suggest that "regional parties may not be the juggernauts many observers make them out to be").

176. GOV'T OF INDIA SECOND ADMIN. REFORMS COMM'N, supra note 2, at iii.

177. See HPEC REPORT, supra note 47, at 87 ("The [74th Constitutional] Amendment is even less clear on the devolution of finances... leaving it to the discretion of state legislatures. State governments have only partially complied with devolution, and this has typically not been accompanied by the devolution of funds and functionaries."); Mohanty, supra note 29, at 123-24 ("[W]ide differences exist between states on the assignment of functions to municipalities.").

178. Political Decentralization, THE WORLD BANK GRP., http://www1.worldbank.org/public sector/decentralization/political.htm (last visited Sept. 24, 2015) (noting that in a federal system such as 
state and local-level reforms would be very difficult to achieve in any federal system, but the enormous economic and social variation between Indian states and Union Territories compounds this challenge immensely.

The biggest challenge for decentralization in India is that the process requires the active participation and consent of states. ${ }^{179}$ There are differing views on the proper balance of power between the states and the municipalities, and in some instances, the central government has overstated the mandate to decentralize. ${ }^{180}$ For example, the Planning Commission of India, in its Twelfth Five Year Plan (2012-2017), stated, "Despite the 74th Constitutional Amendment, which required States to transfer eighteen functions to the ULBs, there is significant variation in devolution of functions, functionaries and funds across the States." ${ }^{\text {"181 }}$ The Planning Commission has since been replaced by the National Institution for Transforming India (NITI) Aayog, ${ }^{182}$ but the Five Year Plan still provides valuable insight into the goals of the JnNURM. In fact, states are not required to devolve authority; rather, it is discretionary. ${ }^{183}$ Indeed, many states have interpreted the provision of Article $243 \mathrm{~W}$ relating to the powers of local authorities as advisory only. ${ }^{184}$ Because implementation is essentially optional, neither states nor municipalities are expressly penalized for failure to implement decentralization goals. ${ }^{185}$ Yet, at the

India, the federal government is "limited in the relationships it may establish with the local level and must seek to affect local behavior and outcomes through the states/provinces").

179. See ThiRTEENTH Fin. COMM'N OF INDIA, supra note 48, at 159 (indicating that changes requiring "consent and active support of State Governments . . can . . . be implemented only in the medium term").

180. See, e.g., SÁEZ, supra note 159, at 140-42 (explaining that several scholars, including K.C. Wheare, believed that India represents a form of cooperative federalism in which federal and regional governments are interdependent while others believed that the two levels of government in a federal system should be independent); Modi Strikes Non-Partisan Note, Says Will Take Opposition Along, TIMES INDIA (June 12, 2014), http://timesofindia.indiatimes.com/india/Modi-strikes-non-partisan-notesays-will-take-opposition-along/articleshow/36413945.cms (drawing attention to Modi's recent use of the term cooperative federalism and explaining that Modi has been using this term to indicate that he wants the central government to forge a better working relationship with the states).

181. TWELFTH Five YeAR Plan - Volume II, supra note 103, at 324 (emphasis added).

182. Cabinet Secretariat Resolution, 2015, No. 511/2/1/2015 Gazette of India, pt. I sec. 1 (Jan. 1 , 2015); Manmohan Singh Faults Modi Govt for Abolishing Planning Commission, ECON. TIMES (June 9, 2015), http://economictimes.indiatimes.com/news/politics-and-nation/manmohan-singh-faults-modigovt-for-abolishing-planning-commission/articleshow/47600859.cms [hereinafter Singh Faults Modi]; NITI Aayog Website Likely to be up on Monday, ECON. TIMES (May 15, 2015), http://articles.economic times.indiatimes.com/2015-05-15/news/62192345_1_niti-aayog-the-aayog-transforming-india [hereinafter NITI Aayog].

183. GOV'T OF INDIA SECOND ADMIN. REFORMS COMM'N, supra note 2, at 9-10.

184. Id. at 22 .

185. Shatkin \& Vidyarthi, supra note 22, at 10; see also S.N. Datye, Panchayati Raj in Maharashtra State, in DyNAmics of New PANChAYATI RAJ SySTEM IN INDIA: SELECT StATES 1, 26 
same time, the lack of a clear delineation of roles and responsibilities also leads to confusion and, at times, interference by the state with what at least some commentators believe are urban affairs. ${ }^{186}$ There have also been calls to amend the Constitution to require state governments to vest power in local authorities and to expand the responsibilities of urban local bodies to make them commensurate with those of the rural local bodies. ${ }^{187}$

Given this constitutional structure, the central government must work through the states to promote decentralization. ${ }^{188}$ Through the JnNURM, the central government incentivized compliance with the 74th CAA by promising funding for infrastructure and basic services. ${ }^{189}$ The scheme represents "the first time that the central government is providing assistance of this kind for what is classified as a State subject as per the Constitution." 190

This analysis suggests that the potential for effective decentralization is limited by both India's constitutional structure and by the language of the provisions authorized by the 74th CAA. Municipalities are not endowed with significant independent power; rather, they must wait for such power to be devolved to them by the states. As a result, states have been reluctant to devolve power to the local level out of fear that it will exacerbate their already subordinate position vis-à-vis the central government. Moreover, as detailed in the next two sections, states do not want to give power to municipalities that lack the capacity and the financial resources to effectively carry out the functions listed in the Twelfth Schedule of the Indian Constitution. In other words, the failure to decentralize

(Ganapathy Palanithurai ed., 2002) (noting that despite the passage of the 73rd and 74th Amendments "even today Panchayats are not vested with power to initiate plan[s] at the district level").

186. GOV'T OF INDIA SECOND ADMIN. REFORMS COMM'N, supra note 2, at 16 (also noting that infrequent elections have hampered the functioning of Indian municipalities); GOV'T OF INDIA SECOND ADMIN. REFORMS COMM'N, supra note 2, at 11-12 ("While there may be rationale for retention of some establishments of the State Government including that of the district administration at the local level, their functions and responsibilities should be confined to areas which are outside the jurisdiction of the local bodies. In respect of devolved functions, local government institutions should have autonomy and must be free of the State Governments' bureaucratic control.”); Kennedy \& Zerah, supra note 71, at 112 (noting that the role of the state government in urban affairs remains central).

187. THIRTEENTH FIn. COMM'N OF INDIA, supra note 48, at 158; GOV'T OF INDIA SECOND ADMIN. REFORMS COMM'N, supra note 2, at i.

188. But see Bandyopadhyay et al., supra note 154, at 63 (observing that while Centrally Sponsored Schemes were historically implemented by the states, at this time, Rajiv Gandhi's government began to bypass the states and reach out to state and local governments directly to help with the implementation of CSS).

189. JNNURM OVERVIEW 3, supra note 74, at 3-4; see also Das, supra note 40, at 116 ("The JNNURM hinges on a carrot-and-stick approach, providing federal funds to select cities conditional upon their agreement to undertake governance reform to become efficient and self-sustaining.").

190. THORNTON, supra note 103, at 253. 
administratively and fiscally negatively impacts the impetus for political decentralization; but many would argue that unless municipalities gain political authority over these functions, they will never have the administrative or financial mandate they need to succeed.

\section{B. Administrative Decentralization}

This article argues that the poor capacity of municipalities to assume the functions identified in the 74th CAA and Twelfth Schedule has been a major stumbling block to achieving the goals of decentralization and the JnNURM. ${ }^{191}$ The limited administrative capacity of local bodies has not only hampered administrative decentralization, it has also discouraged states from transferring political and fiscal authority, creating a Catch-22 situation.

Local bodies have generally been unable to provide basic services to their populations. ${ }^{192}$ While the country arguably lacks capacity at all levels of government, this deficit is particularly acute at the local level. ${ }^{193}$ Most municipalities do not have the specialized and technical skills or staff to oversee the functions to be devolved. ${ }^{194}$ For example, a 2011 assessment found that most municipalities lack the ability to take over functions such as roads, bridges, water supply, sewerage, drainage and urban forestry. ${ }^{195}$

The JnNURM sought to foster administrative decentralization by incentivizing reforms that promoted channels for greater participation in the planning process. For example, it encouraged the development of the

191. GOV'T OF INDIA SECOND ADMIN. REFORMS COMM'N, supra note 2, at 24 ("[T]he matters listed in the Eleventh and Twelfth Schedules could not be fully handled by the local governments even in the best of circumstances."); NAT'L INST. FOR URBAN AFFAIRS, supra note 92, at ix ("It can be argued that, barring exceptional cases, local bodies neither have the technical competence nor information base to take decisions with regard to location of industrial unit, its technology and production links. These do not have the capability to assess the long-term cost implications of the contractual arrangements they are entering into with private companies, for the people or urban economy."); World BANK, ENhancing WATER SERVICE Through PERFormance AgreEMENTs 2 (2009) ("Although the 74th Amendment to the Constitution of India has made urban local bodies responsible for [water supply and sanitation] services, the water departments of these bodies continue to depend extensively on central and state governments for technical and operational direction."); THORNTON, supra note 103, at 84 .

192. GOV'T OF INDIA SECOND ADMIN. REFORMS COMM'N, supra note 2, at 10.

193. Ahluwalia, supra note 108, at 51 ("A state-level municipal cadre is extremely important in driving the process of planning, project preparation and implementation, and city management.").

194. THORNTON, supra note 103, at 266-69 (noting that municipalities need experts in law, project management, finance, social development, e-governance, public works, engineering, urban planning, physical planning, transport, and accounting).

195. Id. at 258; see also ATAL Mission, supra note 113, at 9 (noting that the Atal Mission for Rejuvenation an Urban Transformation hopes to change all this by providing more professional training for municipal workers). 
Metropolitan Planning Committees and the District Planning Committees, ${ }^{196}$ as well as Metropolitan/City Development Commissions. ${ }^{197}$ The scheme stressed the need for more robust and comprehensive planning that has at least a ten-year perspective. It also urged state and local authorities to reassess the boundaries of municipalities as peri-urban areas continue to grow. ${ }^{198}$ While certain provisions were complied with, such as the creation of three tiers of local government, many of the planningrelated committees have not yet been formed. ${ }^{199}$

Capacity building has been described as the "single most important activity required in the today's urban sector scenario." ${ }^{200}$ The JnNURM promoted capacity building efforts by providing project funding tied to 74th CAA reforms. ${ }^{201}$ To the extent that capacity building took place, it was short-term and generally limited to higher-level officials, such as the Mayor, while lower-level officials, such as the engineers responsible for implementation, were excluded. ${ }^{202}$ Funds earmarked for other trainings were not utilized because suitable staff members were not available. ${ }^{203}$

Tensions have arisen because state-level agencies known as "parastatals" are often better equipped than municipalities to handle certain functions. This situation highlights a potential conflict between the goal of improving access to basic services and the devolution of power. Historically, many public services and city planning functions were performed by parastatals, such as development authorities, housing boards, slum development agencies, and water and sanitation boards, many of which were created in the $1970 \mathrm{~s}$ and $1980 \mathrm{~s}^{204}$ These semi-autonomous

196. Ahluwalia, supra note 108, at 51.

197. Twelfth Five Year Plan - Volume II, supra note 103, at 322-24; see also Sivaramakrishnan, supra note 37, at 105-30 (discussing district planning reforms).

198. TWELFTH FIVE YEAR PlAN - VOLUME II, supra note 103, at 327-28.

199. NAT'L INST. OF URBAN AfFAIRS, supra note 21, at vi (noting that "while there has been full compliance in respect of provisions, such as constitution of three types of ULBs, reservation of seats, and constitution of SFCs, the same cannot be said for other provisions, namely constitution of Wards Committees, District Planning Committees and Metropolitan Planning Committees").

200. ThORNTON, supra note 103, at 257; see also GOV'T OF INDIA SECOND ADMIN. REFORMS COMM'N, supra note 2, at 69 (noting that capacity building incorporates both organizational development and individual development).

201. GOV'T OF INDIA SECOND ADMIN. REFORMS COMM'N, supra note 2, at 68-69.

202. Id. at 68; THORNTON, supra note 103, at 267.

203. Twelfth Five Year Plan - Volume II, supra note 103, at 334 (In recognizing these challenges, the Planning Commission recommended that the second phase of the JnNURM reserve approximately ten percent of its overall funds to a separate sub-mission for capacity building.); THORNTON, supra note 103, at 257.

204. GOV'T OF INDIA SECOND ADMIN. REFORMS COMM'N, supra note 2, at 9-10; THORNTON, supra note 103 , at 256 . 
state agencies have specialized expertise. ${ }^{205}$ Sometimes described as agencies or public corporations, parastatals usually have a corporate structure similar to publicly traded private sector companies and a separate legal status from other public service providers. ${ }^{206}$ The "corporatization" of public services has been widely encouraged as an efficient way to manage the delivery of public services because it reduces the potential for political interference and heightens the role of technical experts. ${ }^{207}$

Some parastatals may also be "ring-fenced," meaning that that their budgets are managed separately from the rest of the municipality or state. This strategy, which was encouraged by the High Powered Expert Committee on Urban Infrastructure and the now-defunct Planning Commission of India ${ }^{208}$ (replaced with NITI Aayog by Prime Minister Modi in $2015^{209}$ ), is designed to "create greater financial transparency, reduce political interference, and strengthen managerial accountability within relatively autonomous service entities. ${ }^{210}$ This administrative and political isolation also facilitates raising tariffs for user charges. ${ }^{211}$ However, "ring-fencing" has also been critiqued because some public services should arguably be provided for the safety and health of the community, even though they may not be financially sustainable. Indeed, the strategy can make it more difficult to provide affordable services to the poor and marginalized by preventing cross-subsidization across different sectors. $^{212}$

205. GOV'T OF INDIA SECOND AdMIN. REFORMS COMM'N, supra note 2, at 10; DAVID MCDONALD, RETHINKING CORPORATIZATION AND PubliC SERVICES IN THE GLOBAL SOUTH 1 (2014), http://www.municipalservicesproject.org/userfiles/McDonald_Chap1_Public_Ambiguity_and_the_Mult iple_Meanings_of_Corporatization.pdf.

206. MCDONALD, supra note 205, at 1 .

207. See Id. ("Water and electricity utilities are common examples, although the practice extends to a much wider range of goods and services, including airports, childcare, universities, forests, hospitals, transport and manufacturing.").

208. See HPEC REPORT, supra note 47, at 98 (providing support for the claim that ring-fencing and corporatization in general can lead to significant efficiency gains); TWELFTH FIVE YEAR PLAN VOLUME II, supra note 103, at 333 (encouraging that proceeds accruing to ULBs be set up in a city development fund and "ring-fenced" off for other urban infrastructure projects and for shelter).

209. Cabinet Secretariat Resolution, supra note 182, pt. I sec. 1; Singh Faults Modi, supra note 182; NITI Aayog, supra note 182.

210. MCDONALD, supra note 205, at 2.

211. See Twelfth Five Year Plan - Volume II, supra note 103, at 332 (encouraging the adoption of tariff structures that "not only cover O\&M costs, debt servicing costs and depreciation, but also provide a minimal profit to the ULBs to facilitate creation of an equity base for ULBs over time").

212. See, e.g., David A. McDonald, The Bell Tolls for TheE: Cost Recovery, Cutoffs, AND THE AFFORDability OF MuniCIPAL SERVICES IN SOUTH AFRICA 7 (2002), ftp://healthlink.org.za/ pubs/localgov/ mspreport.pdf; Sharmila Murthy, The Human Right(s) to Water and Sanitation: History, Meaning and the Controversy over Privatization, 31 BERKELEY J. INT'L L. 89, 135 (2013). 
The critical factor for the purposes of this analysis is that parastatals are state-level agencies that are often better positioned to provide services than city-level agencies. Yet, as K.C. Sivaramakrishnan argues, "It is conveniently forgotten that the functional domain of the [urban local bodies] have been steadily undermined by the state governments by setting up parastatals and diverting municipal functions and funds to them., ${ }^{, 13}$

The challenges of achieving administrative decentralization highlight an inherent conflict that was at the heart of the JnNURM: cities may not yet be in a position to improve infrastructure and basic services. In other words, realizing the 74th CAA's goal of municipal empowerment requires a long-term commitment; but, in the interim, the devolution of power to cities could actually hinder the expansion of infrastructure and basic services. The JnNURM attempted to navigate this conflict and strike a balance by permitting the interim use of parastatals. ${ }^{214}$ In addition, many municipalities relied on external consultants to develop the various plans needed to seek and implement JnNURM project-funding.

However, many have criticized such reliance on parastatals because it is perceived as detracting from the goal of municipal empowerment at the core of the 74th CAA. ${ }^{215}$ For example, one national government report on decentralization in India stated, "development authorities should be dissolved and their functions taken over by the local bodies in whose jurisdiction they operate." ${ }^{216}$ The reliance on parastatals could reduce the potential for participatory decision-making by deferring to technical experts who are only indirectly accountable to the people. ${ }^{217}$ Many proponents of decentralization in India see the rise of these parastatal agencies as having a negative effect on local bodies, weakening them and facilitating their "atrophy." 218 There is an effort in some quarters of the

213. SIVARAMAKRISHNAN, supra note 37, at 94-95.

214. See id. at 94 (noting that the JnNURM "guidelines equate parastatal organizations with an elected local body"); TWELFTH FIVE YEAR PLAN - VOLUME II, supra note 103, at 326 (seeing a role for parastatals in a variety of sectors including water supply, solid waste management, sewerage, sanitation, primary health services, primary education, roads and urban transport).

215. Twelfth Five Year Plan - Volume II, supra note 103, at 326; see also Chaubey, Federalism in India, supra note 16, at 5 (suggesting that given the constitutional and political emphasis on decentralization, the role of parastatals, such as state-level authorities, public corporations and other boards, is unclear).

216. THIRTEENTH FIN. COMM'N OF INDIA, supra note 48, at 161, 182 ("It is desirable that all funds relating to local governments be routed through the local bodies and not through any statutory or nonstatutory body whose activities overlap with theirs. All such parallel bodies may be abolished so that funds flow directly to the local bodies through the State Governments.").

217. See HPEC REPORT, supra note 47, at 63 (noting that parastatals are also only indirectly accountable to ULBs).

218. GOV’T OF INDIA SECOND ADMIN. REFORMS COMM’N, supra note 2, at 10. 
Indian government to reverse the "massive decline in the role and status of local bodies" that arose as a result of the parastatals. ${ }^{219}$ Even former Prime Minister Dr. Manmohan Singh urged state governments in 2007 to empower district level institutions, as opposed to state-level parastatals, to handle basic services like water supply. ${ }^{220}$ A seminal report by the Second Administrative Reforms Commission of the Government of India stated:

[T]he parastatal bodies function totally independent from the local governments and are directly accountable to the State Government. Thus, the local governments are often divested of their important functions. Such proliferation of parastatals runs counter to the principle of subsidiarity and precludes effective citizens' participation in the management of these services. The citizen is compelled to deal with a multiplicity of authorities to access even the basic amenities and services. The local functions of all these authorities therefore need to devolve on local governments....221

This critique of parastatals highlights the limits of the 74th CAA to India's Constitution. As discussed supra, the 74th CAA did not mandate the devolution of power from states to local bodies. A municipality's ability to take over administrative functions has impacted state decisions about whether to devolve power. The use of semi-autonomous agencies with discretion is a form of administrative decentralization often referred to as delegation. ${ }^{222}$ This was the type of decentralization promoted in the 1970s and 1980s in India to improve public management. In contrast, the transfer of authority for decision-making, finance, and management to lower tiers of government is usually described as devolution. ${ }^{223}$ This type of administrative decentralization is usually the basis for political decentralization because it provides greater opportunity for citizens and their elected representatives to exert power over public decision-making. ${ }^{24}$

The Modi administration is replacing the JnNURM with its own programs and it has already substituted the Planning Commission with the

219. Id. at iii.

220. See id. at 11 ("I therefore request State Governments to consider empowering district level institutional structures to handle the issue of water supply. This is also a constitutional obligation as water supply is one of the basic functions to be carried out by rural and urban local bodies as per the 11 th Schedule of our Constitution.").

221. Id. at 19.

222. Administrative Decentralization, THE WORLD BANK GRP., http://www1.worldbank.org/public sector/decentralization/admin.htm (last visited Sept. 26, 2015).

223. Id.

224. Id. 
NITI Aayog. ${ }^{25}$ Nevertheless, the Planning Commission's recommendations for the next phase of the JnNURM are still worth considering because many of the central ideas remain, albeit repackaged. ${ }^{226}$ The tremendously overlapping responsibilities of state and city-level institutions in India have resulted in a "mazelike structure of management and accountability."227 The former Planning Commission stressed the need for greater deliberative processes at the local level to institutionalize participatory and accountability mechanisms. ${ }^{228}$ It also suggested a stronger harmonization of parastatals with the elected municipal bodies by encouraging the two bodies to enter into suitable memoranda of understanding, with clearly specified and mutually agreed upon parameters and deliverables. ${ }^{229}$ This type of arrangement is likely preferable to giving the municipalities responsibility at the eleventh hour, especially since the service delivery capacities of municipalities are not always identified before powers are devolved. ${ }^{230}$ This approach would also enable cities to tap into the technical expertise of parastatals, which have a degree of operational autonomy, while simultaneously ensuring a degree of public accountability. ${ }^{231}$ Another option is for local bodies to maintain a common pool of such expertise that could be accessed on demand and by payment. ${ }^{232}$ By providing more accountability to elected municipal officials, this type of arrangement would at least help achieve the spirit of the 74th CAA reforms. ${ }^{233}$

225. Singh Faults Modi, supra note 182; NITI Aayog, supra note 182.

226. See Twelfth Five Year Plan - Volume II, supra note 103, at 28, 325 (citing reforms of the High Powered Expert Committee for Urban Infrastructure); HPEC REPORT, supra note 47, at 94 (noting that the JnNURM is administered by both the Ministry of Urban Development and the Ministry of Housing and Urban Poverty Alleviation, and that the merger of these two ministries is "a prerequisite for taking the agenda of better urban governance forward").

227. Twelfth Five YeAr Plan - Volume II, supra note 103, at 324; see also THORnton, supra note 103, at 258 (noting instances under the JnNURM where new housing construction was not tied to infrastructure or basic service delivery); HPEC REPORT, supra note 47, at 63 (drawing attention to the tortuous accountability system that exists in the field of urban transport).

228. Twelfth Five Year Plan - Volume II, supra note 103, at 326.

229. See THORNTON, supra note 103, at 266 ("For the devolution of functions under 74th CAA, there should be a tripartite agreement between the ULB and parastatal agency to make the ULB accountable for the city functions.").

230. Id. at 257 (noting how "using the structure followed by states like Orissa, [memoranda of agreement] should be signed with the parastatal agencies to permit them to implement the projects with them being accountable to the ULB for the same").

231. HPEC REPORT, supra note 47 , at 63 (noting that currently "the accountability of parastatals is to state government and not to ULBs and thus the latter have little control over the parastatals"); Twelfth Five Year Plan - Volume II, supra note 103, at 325-26; World Bank, supra note 191, at 2.

232. Gov't OF INDIA SECOND ADMIN. REFORMS COMm'N, supra note 2, at 72.

233. Id. at 30-31 (suggesting that the creation of district councils should be accompanied by a change in the responsibilities of the district collector who would be in charge of a wide range of duties 
Any new urban renewal program in India should also be mindful of the challenges that JnNURM faced. The JnNURM required six mandatory reforms at the state level and seven reforms at the municipal level. It also included another ten optional reforms. Failure to achieve these reforms impacted funding for projects and, in some instances, led to cost-overruns and delays. ${ }^{234}$ But weak initial capacity prevented states from devolving power and implementing the reforms in the first place. Thus, before requiring that certain powers necessarily be devolved from the state to the city level, the central government should consider having consultations with the states about what is feasible. ${ }^{235}$ As part of this process, the capacity of the municipalities needs to be assessed. If a city is not yet prepared to assume full responsibility, then the state ought to prioritize ensuring that municipalities are engaged in the process by which parastatal agencies deliver services to citizens. ${ }^{236}$

Effective forms of political, fiscal, and administrative decentralization are intimately interrelated. If municipalities lack the capacity to take up functions envisioned under the 74th CAA, there is reluctance for states to devolve power to them. A municipality's financial position is weakened when it is not able to accrue land-based revenues and financing options that otherwise go to development authorities and parastatals. ${ }^{237}$ But municipalities may not be motivated to assume these functions unless appropriate power and finances are available. ${ }^{238}$ A 2011 evaluation of the JnNURM found that because capacity-building funds were under-utilized during the six year project-span, it was untenable for states to blame municipalities for their lack of capacity. ${ }^{239}$

In some cases, the states may actually work to keep urban local government from functioning efficiently. Typically, the state government assesses the number of people from the backward castes that live in different districts. ${ }^{240}$ This number is important because it influences how many seats in the local government will be reserved for members of the

\footnotetext{
that extend from land acquisition and assessment to maintenance of law and order in both rural and urban areas of a particular district); THORNTON, supra note 103, at 267.

234. THORNTON, supra note 103 , at 256.

235. Id. at 261 .

236. JNNURM OVERVIEW 3, supra note 74, at 12.

237. THIRTEENTH FIN. COMM'N OF INDIA, supra note 48, at 171-72.

238. GOV'T OF INDIA SECOND ADMIN. REFORMS COMM'N, supra note 2, at 81.

239. THORNTON, supra note 103 , at 259.

240. GOV'T OF INDIA SECOND ADMIN. REFORMS COMM'N, supra note 2, at 34.
} 
backward castes. In many cases, states have not shared this information, rendering it impossible for local governments to hold elections. ${ }^{241}$

Another impediment to effective administrative decentralization is the lack of coordination between urban and rural governments. This disconnect is partly attributable to the fact that a system of rural local governance was created before a system of urban governance. ${ }^{242}$ In addition, the rise of new peri-urban areas has made it harder to distinguish areas as clearly urban or rural. ${ }^{243}$ States have also found it difficult to devolve planning powers to local governments when the planning area is larger than city limits. For example, a planning district could cover several municipalities and/or rural areas. ${ }^{244}$ Better coordination between urban and rural local governments is needed because of the expanding peri-urban landscape. ${ }^{245}$

The 74th CAA paved the way for political decentralization, but placed significant discretion at the state level. If municipalities are not administratively capable, then states will have even less incentive to devolve powers to them. The capacity of municipalities to take on increased responsibilities is further impacted by the constitutional limitations on fiscal decentralization, which is discussed next.

\section{Fiscal Decentralization}

The highly centralized nature of India's fiscal federal system complicates the goal of improving municipal financial capacity. This article suggests that fiscal decentralization has not occurred because municipalities do not have the resources to effectively implement newly devolved powers. Consistent with a fiscal federal structure, municipalities have long depended on resources allocated by the national and state governments. Indeed, the JnNURM was a national program that tied financial support to reforms at the state and local levels, an illustration of the centralized manner in which decentralization has been pursued in India. Encouraging cities to diversify their own funding bases and tap into new revenue sources is not only administratively challenging, but also contradicts the theoretical efficiency of a fiscal federal system.

241. See id. at 35-36 (suggesting that the State Election Commissions be given the power to determine the reservation of seats in local government elections).

242. Id. at 30-31.

243. Id.

244. THORNTON, supra note 103, at 256.

245. See GOV'T OF INDIA SECOND ADMIN. REFORMS COMM'N, supra note 2, at 30; NAT'L InST. OF URBAN AFFAIRS, supra note 92, at ix (noting a challenge in that municipalities must often develop plans in an "institutional vacuum" because the district-level or metropolitan level plans are not prepared properly, which reduces the availability of regional and district information). 


\section{India's Fiscal Federal Structure is Highly Centralized}

Fiscal federalism is, at its roots, a theory about how fiscal powers should be divided between multiple levels of government in order to promote allocative efficiency and productive efficiency. This theory holds that the central government should be in charge of macroeconomic stabilization, income redistribution, and the provision of certain "national" public goods. In contrast, subnational governments should be responsible for the provision of local public goods and services. ${ }^{246}$ The centralized collection of resources through taxes and decentralized expenditures is intended to promote allocative efficiency. ${ }^{247}$ As a result, each level of government leverages its own comparative advantage and each subnational actor determines which services deserve the highest priority.

By design, India's constitutional structure features a "vertical mismatch," ${ }^{248}$ also known as a "non-correspondence" problem, ${ }^{249}$ in that the resources collected by the central government far exceed the tasks assigned to it. ${ }^{250}$ Fiscal transfers are required to correct vertical imbalances between different tiers of government. ${ }^{251}$ This intentional mismatch between resource generation and expenditure reflects the idea that many taxes are more efficiently collected by a higher tier of government. ${ }^{252}$ Expenditures are decentralized to improve efficiency because lower levels of government are theoretically better informed. ${ }^{253}$ The fact that that the resources collected by the central government surpass the tasks assigned to it is not inherently problematic. Rather, mechanisms for remedying this asymmetrical taxation are theoretically built into the federal system. It is only when these mechanisms break down that issues arise.

246. See Wallace E. Oates, An Essay on Fiscal Federalism, 37 J. ECON. LIT. 1120, 1120-30 (1999) (noting the presumption of the decentralized provision of public goods with localized efforts).

247. AGARWAL, supra note 15, at 14-15, 25 (describing other economic rationales for federalism, including those based on adequacy, discipline and equity); Mukhopadhayay, supra note 15, at 55 ("In a normative sense, the problem of fiscal federalism is to find the efficient pairing of responsibility for deciding how much of and what kinds of government-provided goods and services to produce with geographically defined subsets of the population." (citation omitted)).

248. Chaubey, Union-State Fiscal Relations, supra note 15, at 22.

249. Mukhopadhayay, supra note 15 , at 58.

250. GOV'T OF INDIA SECOND ADMIN. REFORMS COMM'N, supra note 2, at 226.

251. AGARWAL, supra note 15, at 15-16 (noting also that India's fiscal federal model also tends to exacerbate horizontal imbalances, i.e. between different states within the country).

252. GOV'T OF INDIA SECOND ADMIN. REFORMS COMM'N, supra note 2, at 226 (noting that "[T] Union Government with its nation-wide jurisdiction is better placed to administer taxes like Income Tax, Customs \& Excise Duty and the local government with its intimate knowledge of local conditions is best suited to administer taxes like the Property Tax.").

253. AgARWAL, supra note 15, at 15; Andres Rodriguez-Pose \& Nicolas Gill, The Global Trend Towards Devolution and Its Implications, 21 ENV'T. \& PLAN. 333 (2003) (discussing the efficiency advantages lower level governance can engender). 
India has utilized two primary mechanisms for remedying intentionally asymmetrical taxing and spending between the central and state governments. ${ }^{254}$ First are transfers to the states via the Finance Commission, a unique institution without a parallel in other federal countries. $^{255}$ Convened every five years, the Finance Commission makes recommendations about collected taxes and duties, which it is constitutionally required to divide between the central government and states. ${ }^{256}$ The share of proceeds of central taxes to be divided between the Center and the states is known as vertical distribution, while the share to be divided between the states is known as horizontal distribution. ${ }^{257}$ Plan transfers by the Planning Commission were the second mechanism for transferring funds to the states, ${ }^{258}$ but as noted earlier, this institution has since been dissolved. ${ }^{259}$ The Planning Commission was established as a permanent body in 1950 and played a critical role in developing schemes when India's public sector played a large role in the economy. ${ }^{260}$ The Planning Commission was considered "extra-constitutional" because it was not explicitly referenced in the Constitution. ${ }^{261}$ Rather, its power derived

254. See Mahendra Prasad Singh, Indian Federalism: An Introduction 151 (2011) (describing "four major channels of fiscal transfers from the Union to the State: (a) through the constitutionally entrenched Finance Commission of India, (b) through the extra-constitutional (though not unconstitutional) Planning Commission created by a cabinet resolution of the Nehru government in 1951 , (c) through the Union ministries via centrally sponsored schemes in Union, State, and Concurrent jurisdictions alike, and (d) through central grants-in-aid for disaster management, if and when one occurs.").

255. See generally INDIA CONST. art 280 (stating in part: “(1) The President shall, within two years from the commencement of this Constitution and thereafter at the expiration of every fifth year or at such earlier time as the President considers necessary, by order constitute a Finance Commission which shall consist of a Chairman and four other members to be appointed by the President."); AGARWAL, supra note 15, at 5, 43, 46 (noting that under the 80th Amendment to the Constitution of India, Article 270 was significantly revised and Article 272 was omitted); AGARWAL, supra note 15 at 48 ("The Finance Commission is responsible for forecasting the revenues and expenditures of the Center and states, and then for developing a formula for distribution."); Chaubey, Federalism in India, supra note 16 , at 4,7 .

256. INDIA CONST. art. 275; AGARWAL, supra note 15, at 44 (indicating that these are made via divisible taxes and duties under Articles 269, 270 and 273 and grants in aid under Article 275); Chaubey, Union-State Fiscal Relations, supra note 15, at 23, 34.

257. Mukhopadhayay, supra note 15, at 61-64 (noting that the Finance Commission has the authority to provide grants-in-aid, which are above and beyond the sharing of revenue and are generally designed to cover non-Plan revenue gaps).

258. AgARWAL, supra note 15 , at 43 . Given that the Planning Commission was replaced by NITI Aayog in 2015 by Prime Minister Modi, the future mechanism for such transfers is unclear.

259. Singh Faults Modi, supra note 182.

260. Vikas Dhoot, Planning Commission an Old House That Can't Be Repaired: Narendra Modi, ECON TIMES (Aug. 16, 2014), http://articles.economictimes.indiatimes.com/2014-08-16/news/528736 64_1_systems-reform-commission-planning-commission-independent-evaluation-office.

261. Chaubey, Federalism in India, supra note 16, at 4. 
from Article 282 of the Constitution, which enabled it to provide grants for any public purpose. ${ }^{262}$ Additionally, the Planning Commission's five-year plans usually provided for discretionary transfers via central schemes, such as the JnNURM, which were managed by union ministries. ${ }^{263}$ Approximately two-thirds of resources had been transferred via the Finance Commission and one-third had been transferred through the Planning Commission. ${ }^{264}$ As discussed below, states were then responsible for disbursing funds to the local level. Given the current functions of the NITI Aayog, ${ }^{265}$ it is not yet clear what role it will play in allocation of resources to the states.

India's fiscal federal system has been complicated by a perceived duplication of effort between the Finance Commission and the Planning Commission. The Finance Commission was initially envisioned to be the chief, or exclusive, mechanism for transferring funds between the central and state governments through a process intended to be free of political interference. ${ }^{266}$ The Planning Commission gained increasing power because of its ability to target funding to projects deemed important by the Center. This power made the Planning Commission the "unintended channel" for transferring resources, leading to a perception that it was dominant. ${ }^{267}$

Given the duplication of effort between the Finance Commission and the Planning Commission, it was suggested that the two institutions merge. ${ }^{268}$ Soon after taking office, Prime Minister Modi indicated that he

262. Chaubey, Union-State Fiscal Relations, supra note 15, at 23.

263. See AgARWAL, supra note 15, at 43; Chaubey, Union-State Fiscal Relations, supra note 15, at 23 .

264. Singh, supra note 128, at 12; Twelfth Five YeAR Plan - Volume I, supra note 47, at 81 (noting that of the amounts allocated by the 12th Five Year Plan (2012-2017), approximately $75 \%$ of gross budget support went to the Center, including predominantly to centrally sponsored schemes, and the remaining 25\% went to the states); Mukhopadhayay, supra note 15, at 66 .

265. Functions, NITI AAYOG, GOV'T OF INDIA, http://niti.gov.in/content/functions.php (last visited Sept. 23, 2015).

266. Singh, supra note 128 , at 12.

267. AGARWAL, supra note 15, at 59; Chaubey, Union-State Fiscal Relations, supra note 15, at 23; Rao \& Singh, supra note 136, at 53 (noting that the first Finance Commission recommended that a permanent organization to study state finances be created. There has been some speculation that the failure to implement this recommendation was a deliberate attempt to restrict the scope of the Finance Commission relative to the Planning Commission); Dhoot, supra note 260 (noting that the influence of the Planning Commission waned in the 1980s and 1990s as economic liberalization allowed a greater role for the private sector, but its influence has been prominent in recent years); Singh, supra note 128, at 15 (noting that the fact that the Planning Commission is a permanent body, while the Finance Commission is convened anew every five years, has also given greater authority to the Planning Commission).

268. Singh, supra note 128 , at 15 . 
would replace the Planning Commission with a new organization. ${ }^{269}$ While the proposed institution was originally supposed to be called the National Development Reforms Commission (NDRC), ${ }^{270}$ it ultimately became the NITI Aayog. As the Cabinet Resolution creating the NITI Aayog notes, the rise of "market forces and larger global shifts" means that there is also a "diminished role of centralised [sic] planning." ${ }^{271}$ As this article was going to press, the future of the NITI Aayog remained unclear.

While a fiscal federal structure is intended to be centralized with respect to collection, India's approach historically limited the extent to which expenditures could be decentralized. For over 50 years, India's constitutional structure only allowed certain resources to be shared with the states, which reinforced the centralized nature of India's federal model. This approach was also at odds with the theory of federalism. ${ }^{272}$ In 2000 , India's Constitution was changed through the 80th Amendment so that all taxes and duties collected by the union could be shared with the states. ${ }^{273}$ Yet even under the revised provisions, certain revenues must be shared with the states and others may be shared. ${ }^{274}$

An appropriately designed fiscal federalism system requires both adequate resources to discharge responsibilities, as well as elasticity of resources to meet preferences and needs. Yet, this economic theory needs to mesh with the political reality in India. While the states are equal as a matter of law, in many respects, they are politically in a subordinate position because they depend on the Center for funding. ${ }^{275}$ The central government's ability to call "President's Rule" also reinforces the inferior

269. See Dhoot, supra note 260.

270. Sanjeeb Mukherjee, New Body Set to Replace Planning Commission, Bus. STANDARD (Aug. 16, 2014), http://www.business-standard.com/article/economy-policy/new-body-set-to-replaceplanningcommission-114081600035_1.html.

271. See Press Note, Cabinet Secretariat, Gov't of India, Government Constitutes National Institution for Transforming India (NITI) Aayog (Jan. 1, 2015), http://pib.nic.in/newsite/Print Release.aspx?relid=114268. See also Puja Mehra, Move to Scrap Planning Commission Raises Constitutional Questions, HINDU (Aug. 17, 2014), http://www.thehindu.com/news/national/move-toscrap-planning-commission-raises-constitutional-questions/article6324619.ece (raising numerous concerns about the original proposal); Singh Faults Modi, supra note 182 (criticizing the replacement of the Planning Commission with NITI Aayog).

272. AGARWAL, supra note 15, at 58 (noting that previously, only income and excise taxes could be shared with the states).

273. Id. at 5; Chaubey, Union-State Fiscal Relations, supra note 15, at 28 (describing the 89th Amendment bill passed by the Indian parliament as more "revolutionary" than originally intended). See also id. at 26 (describing the original provisions as "clumsy and unnecessary" as well as "baffling and mind boggling" because they made "meticulous distinction" between items that had to be distributed under Article 270 (income tax) and those that could be distributed under Article 272 (excise duty)).

274. Chaubey, Federalism in India, supra note 16, at 7.

275. See Chaubey, Union-State Fiscal Relations, supra note 15, at 21. 
position of the states. ${ }^{276}$ The states' ability to borrow from the market is also limited, which only heightens this dependence. ${ }^{277}$ In reality, discretionary control of resources by the Center combined with the decentralized expenditure by the states has also contributed to fiscal irresponsibility at the state level. ${ }^{278}$ While the fiscal federal model calls for the decentralization of expenditures, the subordinate position of the states, strong centralizing tendencies in India, and concerns about fiscal irresponsibility have limited the extent to which this is possible.

The relationship between the Center and the states mirrors that between the states and municipalities. The Central Finance Commission (CFC) requires the fair and equitable transfer of resources from the Center to the states, ${ }^{279}$ and the 74th CAA established a similar arrangement between the states and local bodies through the creation of State Finance Commissions (SFC) ${ }^{280}$ As constitutionally created bodies, the SFCs enable the state governments to devolve funds to local bodies and to authorize local bodies to impose taxes and duties. ${ }^{281}$ Every five years, the SFCs are required to review the financial positions of the municipalities. ${ }^{282}$ Just as the CFC makes recommendations about how funds should be divided between the Center and the states, the SFCs are required to make recommendations as to how funds should be split between the states and local bodies. ${ }^{283}$

While the 74th CAA outlined eighteen functions that states may devolve to the municipalities, ${ }^{284}$ as set forth in the Twelfth Schedule, it did not provide a corresponding "municipal finance list." Rather, states have discretion to assign finances to municipalities "by law." Although states are

276. Aseema Sinha, Political Foundations of Market-Enhancing Federalism: Theoretical Lessons from India and China, 37 COMP. POL. 337, 344 (2005).

277. AGARWAL, supra note 15, at 40; Mukhopadhayay, supra note 15, at 58.

278. Mukhopadhayay, supra note 15, at 65; see also A.C.K. Nambiar, Federal State Financial Relations in India: The Post-Liberalisation Period, in FISCAL FEDERALISM IN INDIA, supra note 15, at 53; Chaubey, Union-State Fiscal Relations, supra note 15, at 34-36.

279. See INDIA CONST., art. 280.

280. Gov'T OF INDIA SECOND ADMIN. REFORMS COMM'N, supra note 2, at 226; See India Const., art. $243 X$.

281. See INDIA CONST., art. 243 (noting that the power of the municipalities is derived from the state government and devolved at the discretion of the state).

282. GOV'T OF INDIA SECOND ADMIN. REFORMS COMM'N, supra note 2, at 61, 66 (noting that SFCs are tasked with assessing the resource gaps in all urban and rural local bodies and developing a plan to transfer funds).

283. Id. at 61 .

284. AtAL Mission, supra note 113, at 30 (noting that the Modi's new urban renewal scheme, the Atal Mission for Rejuvenation and Urban Transformation, will provide additional funds to those states that devolve these 18 powers down to ULBs). 
limited in the taxes that they can collect, those for which they have responsibility can also be assigned to local governments. These include property taxes, vehicle taxes, professional taxes, and octroi, to the extent this last category still exists. ${ }^{285}$ As a result, the constitution reinforces a structure whereby states are highly dependent on the central government, and in turn, the municipalities are highly dependent on the states. ${ }^{286}$

\section{Numerous Barriers Exist to Municipal Fiscal Empowerment}

Despite the breadth of functions that are to be devolved to municipalities, a commensurate amount of resources has not also been devolved. ${ }^{287}$ Local bodies across India require financial support to provide core services, such as drinking water, sewerage, solid waste management, and street lights, and to provide for operational infrastructure and staffing. ${ }^{288}$ Their lack of funding is a key reason for the poor operation and maintenance of urban infrastructure and inadequate service delivery.

The JnNURM sought to improve access to funding for municipal infrastructure and delivery of basic services by incentivizing reforms at the local and state level designed to promote the 74th CAA. ${ }^{289}$ The JnNURM fiscal reforms were broadly focused on three areas. The first area was the development of more effective SFCs in order to reduce delays in the transfer of funds to municipalities. The second area involved increasing the revenue base through improved taxation and user charges for public services, such as water supply. The third area entailed private sector participation in the delivery of public services. ${ }^{290}$ Each of these is discussed in turn.

285. AGARWAL, supra note 15 , at 38-39.

286. MOHANTY ET AL., supra note 2, at i.

287. Id. at viii, 6; GOV'T OF INDIA SECOND ADMIN. REFORMS COMM'N, supra note 2, at 223.

288. THIRTEENTH FIN. COMM'N OF INDIA, supra note 48, at 173.

289. Ministry OF URBAn EMP'T \& POVERTY AllEVIATION \& Ministry OF URBAN DeV., supra note 74 , at 12-13 (noting that other JnNURM state-level reforms include reforming rent control laws, reducing stamp duty, enacting public disclosure laws and community participation laws, and expanding the role of elected municipal officials in city planning).

290. GOV'T OF India SECOND AdMIN. REFORMS COMM'N, supra note 2, at 232-33; NAT'L InST. OF URBAN AFFAIRS, supra note 21, at vii (finding that, as of 2005, "there exists a problem of ineffective participation in the decision-making process despite adoption of the policy of reservation, delays in the transfer of funds to the municipalities despite constitution of State Finance Commissions, poor recovery from various tax and non-tax sources despite devolution of powers, etc."); THORNTON, supra note 103, at 118 . 


\section{a. State Finance Commissions (SFCs)}

State Finance Commissions often do not function properly, which negatively impacts the financial revenues of a municipality. ${ }^{291}$ The quality of SFC reports is inconsistent, due in part to the lack of data from urban and local bodies, limited capacity, and lack of ownership by state governments. ${ }^{292}$ The Central Finance Commission has recommended that SFC reports follow a uniform template and adopt reporting periods that are synchronous with the CFC reports. ${ }^{293}$ SFCs are urged to conduct more thorough analyses of the municipalities' finances to make recommendations regarding the efficiency of tax collection, expenditures, operational efficiencies, and other related issues. ${ }^{294}$ With the goal of incentivizing the delivery of quality public services, the CFC has also recommended that SFCs consider linking the devolution of funds to the level/quality of civic amenities that the citizens could expect. ${ }^{295}$ SFCs are also encouraged to produce reports that are more consistent, thorough, and transparent.

Even where SFCs are functioning well, state governments often do not follow their recommendations and, as a result, do not commit adequate resources to local governments. ${ }^{296}$ In contrast, the central government of India generally accepts the recommendations of the CFC, even though they are not mandatory. ${ }^{297}$ When states do not implement the recommendations of SFCs ${ }^{298}$ the transmission of funds to local bodies is delayed despite the fact that states have to pay interest to the local bodies. ${ }^{299}$ Resultantly, many municipalities have unpredictable funds transfers from state governments, ${ }^{300}$ which compromise their ability to discharge their

291. NAT'L INST. OF URBAN AFFAIRS, supra note 21, at vi ("Municipalities historically faced numerous challenges, including inefficiency in the conduct of business, ineffective participation by the weaker sections of the population in local governance, weak financial condition, lack of transparency in the planning and implementation of projects, etc.”); Rao \& Bird, supra note 32, at 219.

292. THIRTEENTH FIn. COMM'N OF INDIA, supra note 48, at 171.

293. Id. at $158-71$.

294. GOV'T OF INDIA SECOND ADMIN. REFORMS COMM'N, supra note 2, at 66-67.

295. Id. at 66 .

296. Id. at 65 .

297. Id.

298. MOHANTY ET AL., supra note 2, at 1-2 ("Following the recommendations of the State Finance Commissions (SFCs) and taking into account the devolutions made by the Central Finance Commission (CFC), the State Governments are required to devolve resources to their local bodies."); Mohanty, supra note 29 , at 128 .

299. THIRTEENTH FIN. COMM'N OF INDIA, supra note 48, at 167.

300. See HPEC REPORT, supra note 47, at 128. 
responsibilities. ${ }^{301}$ The reluctance of states to follow the recommendations of SFCs that are working well is yet another barrier to improvements in municipal finance in India. ${ }^{302}$

\section{b. Expanding Revenue Base}

Local bodies in India suffer from a lack of an independent tax base. ${ }^{303}$ The sources of municipal revenues in India - taxes, user charges and fees, transfers, and loans - are relatively narrow compared to international benchmarks and other federal countries like the United States, Canada, Brazil, and China. ${ }^{304}$ For example, while local government revenues in the U.S. accounted for fifteen percent of total government revenues in 2001, the figure in India was only three percent. ${ }^{305}$ There are four ways for Indian local bodies to try to expand their revenue base, but each strategy faces challenges.

First, municipalities can persuade state governments to devolve more sources of revenue down to them. Even though the urban population in India is growing faster than the national rate, municipalities are increasingly dependent on the Center and states for financial resources. ${ }^{306}$ However, the states have been historically reluctant to share any financial resources with local bodies, which stems in part from the lack of administrative capacity (as discussed in Section III.B) and in part from their sense of marginalization by the central government (as discussed in Section III.A). ${ }^{307}$ Ironically, the inability of municipalities to generate

301. See THIRTEENTH FIN. COMM'N OF INDIA, supra note 48, at 149, 161. But see NAT'L INST. OF URBAN AFFAIRS, supra note 21, at $\mathrm{x}$ (noting that "reports prepared to assess the status of SFC recommendations show that the proportion of recommendations accepted (either fully, partly or in a modified form) is much higher than those which have not been accepted.").

302. See AtAl Mission, supra note 113, at 30 (indicating that Modi's new urban renewal scheme, the Atal Mission for Rejuvenation and Urban Transformation, will incentivize states to adopt SFC recommendations within an 18 month time period).

303. See Mohanty, supra note 29, at 128 (describing why "the framework of revenue assignment in the 74th Amendment Act is incomplete"); Rao \& Bird, supra note 32, at 213 ("In India, it is clear that lack of adequate resources is one key reason for municipal bodies not providing satisfactory levels of the assigned public services.").

304. See MohantY ET AL., supra note 2, at iii, viii-ix, 160 (noting that Indian ULBs collect and spend considerably less per capita than their counterparts in Poland, South Africa, and Brazil. The only exception to this rule is Mexico whose local bodies collect and spend approximately the same amount per capita as local bodies in the Indian state of Maharashtra); see also Mohanty, supra note 29, at 129 (showing a list of revenue sources in Table 5.3).

305. GOV'T OF INDIA SECOND ADMIN. REFORMS COMM'N, supra note 2, at iii.

306. Id. at 223-24.

307. THIRTEENTH FIN. COMM'N OF INDIA, supra note 48, at 136-37. 
matching funds has, at times, impeded their ability to participate in many central government schemes. ${ }^{308}$

Second, local bodies can try to raise new sources of tax revenue. ${ }^{309}$ Such a strategy may be politically difficult, however, as many have expressed an aversion to introducing new taxes until the current tax administration system is improved. In India, tax evasion is widespread at the national, state and local level. ${ }^{310}$ For example, in 2012, the Chief of India's Central Bureau of Investigation reported that over 500 billion dollars have been illegally deposited in overseas tax havens. ${ }^{311}$ Until citizens have faith in the government's ability to ensure compliance with existing tax measures, it will be difficult to secure public support for new tax measures at any level of government.

Third, local bodies can improve the efficiency and utilization of existing revenue collection mechanisms. Property tax is the most important source of revenue for local governments ${ }^{312}$ because land is a municipality's biggest asset. ${ }^{313}$ However, only approximately sixty to seventy percent of most urban properties in India are taxed. Unsatisfactory records of property title, urban sprawl that expands municipal boundaries, unauthorized construction, and corruption all complicate the collection of property taxes. ${ }^{314}$ Unintentional conflicts arise with state agencies as well. For example, if a state-level parastatal agency develops an area, then it may not be handed over to a municipal body for some time, preventing the collection of local taxes. ${ }^{315}$ In order for there to be an improvement in property tax collection, these urban management issues need to be addressed.

308. NAT'L INST. OF URBAN AFFAIRS, supra note 92, at xii.

309. Savage \& Dasgupta, supra note 24, at 48 ("Traditionally, the provision of urban infrastructure and services has been among the primary functions of the government where the funding of complete service delivery is sourced out of tax revenues.").

310. 100 Big Traders May Be Netted for Local Body Tax Evasion, TiMES INDIA (Aug. 6, 2014), http://timesofindia.indiatimes.com/city/nagpur/100-big-traders-may-be-netted-for-local-body-taxevasion/articleshow/39708736.cms.

311. India 'Loses \$500bn to Tax Havens', BBC NEws (Feb. 13, 2012), http://www.bbc.com/news/ world-asia-india-17013314; Ministry of Finance Seeks Help in Recovery of Tracing Tax Defaulters, TIMES INDIA (Aug. 30, 2015), http://timesofindia.indiatimes.com/business/ india-business/Ministry-ofFinance-seeks-help-in-recovery-of-tracing-tax-defaulters/articleshow/48728 848.cms (noting that this problem has become so severe that the Indian Ministry of Finance recently reached out to the public for help tracking down "high value" income tax defaulters).

312. Gov'T OF India SECOND AdMin. ReFORMS COMM'N, supra note 2, at 227 (noting that local governments generally administer property tax because that requires an understanding of local conditions); Rao \& Bird, supra note 32, at 215.

313. THORNTON, supra note 103, at 268.

314. GOV'T OF INDIA SECOND ADMIN. REFORMS COMM'N, supra note 2, at 228.

315. THORNTON, supra note 103, at 268. 
Fourth and finally, local bodies can try to mobilize non-tax sources of revenue by charging user fees for the provision of public services, such as water and sewerage. ${ }^{316}$ User fees for municipal services are difficult to implement because they require a level of political acceptance and consensus. ${ }^{317}$ Unclear land tenure, for example in slums, may prevent a municipality from installing service connections, even when residents may be willing to pay for such connections. ${ }^{318}$ User fees set at rates too high to be affordable may also impose public health costs and create human rights consequences. While the imposition of user fees may represent a significant opportunity for municipalities looking to expand their revenue base, the potential for these fees to further marginalize the urban poor or pose public health risks needs to be carefully considered.

\section{c. Private Sector Participation (Market-Based Decentralization)}

Indian municipalities are increasingly turning to the private sector to fund infrastructure improvements and the delivery of basic services. ${ }^{319}$ The term market-based decentralization is used to identify situations in which decentralization is associated with the transfer of responsibilities not to lower levels of government, but to private companies. There are two ways that private companies are becoming involved in urban infrastructure financing: they are working with local governments to provide services for a certain percentage of the revenue (public-private partnerships), and they are lending money to municipal governments, for example in the form of municipal bonds.

The JnNURM also embraced market-based decentralization by encouraging ULBs to borrow from capital markets and engage in public private partnerships (PPPs). The JnNURM was the first major scheme of the government of India that fostered PPPs in urban sectors such as solid waste, water supply, sewage, and urban transport. The JnNURM helped facilitate municipal borrowing from capital markets by working with four major credit agencies to make sure the JnNURM cities all had credit ratings. ${ }^{320}$ The newly formed NITI Aayog will also likely embrace a greater

316. MohANTY ET AL., supra note 2, at 40; Mohanty, supra note 29, at 136-37; Rao \& Bird, supra note 32 , at 214 .

317. THORNTON, supra note 103, at 258.

318. See generally Sharmila L. Murthy, Land Security and the Challenges of Realizing the Human Right to Water and Sanitation in the Slums of Mumbai, India, 14 HeAlth \& HuM. RTS. (2012).

319. Anand Sahasranaman \& Vikram Kapur, The Practice of PPP in Urban Infrastructure, in URBANISATION IN INDIA: CHALLENGES, OPPORTUNITIES AND THE WAY FORWARD, supra note 29, at 176, 176; SIVARAMAKRISHNAN, supra note 24 , at 173-75.

320. See Union Budget 2014-15: Stress on Development of Urban Areas, ZEE MEDIA BuREAU (July 10, 2014), http://zeenews.india.com/business/indian-budget-2014/union-budget-2014-15-stress- 
role for the private sector. Indeed, the Cabinet Resolution that created the NITI Aayog states that "[i]n the past, governance may have been rather narrowly construed as public governance. In today's changed dynamics with 'public' services often being delivered by 'private' entities, and the greater scope for 'participative citizenry', governance encompasses and involves everyone." 321

The direct borrowing model for private sector investment and the PPP model have both had limited success in India so far. One form of direct borrowing - municipal bonds - was believed to be an especially promising way to finance urban infrastructure. ${ }^{322}$ Municipal bonds were seen as particularly attractive because of their greater borrowing potential ${ }^{323}$ and longer maturity periods. ${ }^{324}$ While over twenty municipal bonds were issued in the late 1990s and 2000s ${ }^{325}$ there have been no municipal bonds issued since 2010. This recent stagnation of the municipal bond market has been attributed to low municipal credit scores and the lack of a sound regulatory framework. However, there are a number of indications that India is looking to revive its municipal bond market. In January 2014, India's capital regulator announced the creation of a "twenty-odd" person committee that will make recommendations about how to facilitate the development of the municipal bond market. ${ }^{326}$ In July 2014, India's Finance Minister announced a ten-fold increase in funds for an organization dedicated to improving municipal credit scores and infrastructure projects. ${ }^{327}$ There have also been suggestions that municipal bonds may be used, at least in part, to fund Modi's "Smart Cities" plan. ${ }^{328}$ The recently released guidelines indicate that Modi's new urban renewal

on-development-of-urban-areas_103615.html [hereinafter Union Budget] (acknowledging the "participation of several banks to promote and finance infrastructure projects"); ATAL MISSION, supra note 113 (noting that the Atal Mission for Rejuvenation and Urban Transformation aims to finish what the JnNURM started and issue credit ratings for those urban local bodies that have not yet received a rating).

321. Cabinet Secretariat Resolution, supra note 182, at 8.

322. Sahasranaman \& Kapur, supra note 319, at 181.

323. Shahana Sheikh \& Mukul Asher, A Case for Developing the Municipal Bond Market in India, 42 ASCI J. MGMT. 1, 4 (2012).

324. In finance, a maturity refers to the "specific date at which the principal amount of the bond is repaid." STEPHEN A. Ross ET AL., FundAMENTAls of CORPORATE FinANCE 194 (4th ed. 2001).

325. Sheikh \& Asher, supra note 323, at 6.

326. Manju Dalal, India to Boost Muni Market, ReUTERS (Jan. 17, 2014), http:// www.reuters.com/ article/2014/01/17/india-bonds-municipal-idUSL2N0KQ0IB20140117.

327. Union Budget, supra note 320.

328. Arup Roychoudhury, Municipal Bonds May Help Finance Smart Cities, FIN. EXPRESS (Aug. 7, 2014), http://archive.financialexpress.com/news/municipal-bonds-may-help-finance-smart-cities/127 $7156 / 1$ 
scheme, AMRUT, will also try to increase the availability of municipal bonds. $^{329}$

As with municipal bonds, the extent to which PPPs will be used to finance urban infrastructure is unclear. ${ }^{330}$ One large concern about PPPs is the potential for collusion between companies and bureaucrats. This concern has prompted some, including recent Nobel Prize winner Jean Tirole, to argue for independent evaluation of PPP contracts. ${ }^{331}$ Another potential way to prevent collusion between public and private partners is to allow the Comptroller and Auditor General (CAG) of India to audit publicprivate partnerships. In August 2014, the CAG asked the government for this authority. ${ }^{332}$ If these concerns about collusion can be addressed, PPPs could be a very important source of urban infrastructure financing. ${ }^{333}$ The Planning Commission, which has since been replaced with NITI Aayog, estimated that between thirteen and twenty-three percent of urban sector investments could potentially be made using the PPP model. ${ }^{334}$ The authors of the Twelfth Year Plan obviously envisioned a future for the PPP model seeing as they used it as the basis for their new experiment in melding the language of political and market-based decentralization.

The Twelfth Five Year Plan (2012-2017) also called for an extended "4P" framework-People-Private-Public-Partnerships. Experience across the world indicates that in urban renewal and management, the role of people in the design of projects and partnerships is more crucial than in large infrastructure projects such as highways, airports, power plants. ${ }^{335}$ India's new Prime Minister, Narendra Modi, has also embraced the PPPP model, as illustrated by a recent blog post on his website. ${ }^{336}$ In fact, the guidelines of Modi's new urban renewal scheme, AMRUT, state the

329. ATAL MisSiON, supra note 113, at 67.

330. See Ahluwalia, supra note 108, at 54 ("One area in which JNNURM has not been successful is in motivating ULBs to tap external sources of funding through municipal bonds and/or PPP.").

331. Mihir Sharma, Four Nobel-Winning Insights that Matter for the Indian Economy, Bus. STANDARD (Oct. 14, 2014), http://www.business-standard.com/article/opinion/four-nobel-winninginsights-that-matter-for-the-indian-economy-114101301188_1.html.

332. See Vikas Dhoot, UPA Government Blocked Reforms to Empower CAG:Vinod Rai, ECON. TIMES (Sept. 15, 2014), http://articles.economictimes.indiatimes.com/2014-09-15/news/53942910_1_ vinod-rai-cag-comptroller-auditor-general.

333. CAG Asks Government to Ensure All Accounts of PPP Projects Are Audited, ECON. TIMES (Aug. 4, 2014), http://articles.economictimes.indiatimes.com/2014-08-04/news/52428582_1_apexauditor-cag-auditor-general.

334. TWELFTH FIVE YEAR PLAN - VOLUME II, supra note 103, at 333.

335. Id. at 332.

336. People Public Private Partnership, NARENDRAMODI.IN, http://www.narendramodi.in/ people-public-private-partnership/ (last visited May 22, 2014). 
government's intention to use the PPPP model to finance the upkeep of parks, playgrounds, and other recreational areas. ${ }^{337}$

When India's "Smart Cities" plan goes into effect, the role played by the private sector will increase. The plan's draft concept note states that a city covered under the plan "must be able to attract investments and funds from private players, ${ }^{, 338}$ including from municipal bonds and PPPs. More specifically, the plan recommends that creditworthy local governments issue tax-free municipal bonds and deploy PPPs as a means of leveraging private sector financing. ${ }^{339}$ India's Urban Development Minister recently remarked that "the key to building smart cities is private investments." 340

India is in the midst of an important shift in the financing of urban infrastructure $;{ }^{341}$ less than a decade ago, the private sector played a much smaller role. The JnNURM encouraged the use of two forms of marketbased financing: PPPs and municipal bonds. Although each financing mechanism comes with its own set of challenges, both mechanisms are still believed to offer some promise. While the JnNURM will soon be phased out, private sector investment will likely continue to play a large role in urban financing under Modi's "Smart Cities" plan. ${ }^{342}$

\section{Greater Coordination is Needed}

The inadequate administrative capacity of municipalities combined with the poor functioning of the SFCs has meant that municipalities are not in a position to discharge their increased responsibilities. It should thus come as no surprise that a recent evaluation of the JnNURM stated that while the scheme "has brought about a change in the mindset of the States' and the ULBs' [urban local bodies] to focus more on strengthening their financial and technical capabilities, there is still a long way to go before they will be in a position to reduce their dependence on funding via grants from the Central and/or State Government.",343

Fiscal decentralization in India is plagued by the reality that without an effective means for remedying the "vertical mismatch," it is challenging to implement fiscal federalism. The irony is that this push towards

337. Atal Mission, supra note 113, at 29.

338. Draft Concept Note on Smart City Scheme, supra note 8, at 44.

339. Id. at 41 .

340. Private Investments to Help Develop 100 Smart Cities Planned by Govt: Venkaiah Naidu, ECON. TIMES (Sept. 27, 2014), http://articles.economictimes.indiatimes.com/2014-09-27/news/543771 03_1_100-smart-cities-private-investments-urban-local-bodies.

341. See generally Sahasranaman \& Kapur, supra note 319, at 188.

342. See AtAl Mission, supra note 113, at 10.

343. THORNTON, supra note 103, at 252. 
expanding the municipal resource base contradicts the basic premise of the supposed allocative efficiency of fiscal federalism. An assumption implicit in this theory is that functions discharged at the local level can be financed by higher levels of government. ${ }^{344}$ Indeed, the theory of public finance indicates that the central government of India is better positioned to address re-distribution challenges through centralized revenue collection followed by inter-governmental transfers. However, a report prepared by the research arm of the Reserve Bank of India has observed that "there is no appropriate model of inter-governmental finance for local bodies in India to tackle the colossal problem of urban poverty." $" 345$ In other words, the theory of fiscal federalism that drove India's centralized system of tax collection will not work unless there are adequate policy mechanisms to enable the lowest tiers of government to spend the collected revenue. Greater consultation and partnership across all levels of government in India is needed to fulfill the promise of cooperative federalism. ${ }^{346}$

Although the 74th CAA and the municipal reforms promoted by the JnNURM sought to empower municipalities, these local bodies do not have significant independent power and have simply implemented central and state government schemes. ${ }^{347}$ Persistent resource constraints impede the states' ability to allocate sufficient resources down to the municipalities. ${ }^{348}$ Because the states are unable to adequately provide for local governments, the Center increasingly has an "indirect stamp" on urban affairs through schemes like the JnNURM. ${ }^{349}$ Given the detailed instructions in the Twelfth Five Year Plan on urban planning and renewal, an irony is apparent: India has taken a highly centralized approach to creating decentralization. Indeed, the JnNURM was criticized for the dominant role of the Center vis-à-vis the states and for inadequate focus on the political processes needed to strengthen municipalities. ${ }^{350}$

344. MOHANTY ET AL., supra note 2, at viii.

345. Id. at 6. See also Chaubey, Federalism in India, supra note 16, at 3 (recognizing that India's approach to structuring the government has shifted between emphasizing provincial autonomy and federal centralization in recent history); Mukhopadhayay, supra note 15, at 66 (suggesting that the "kaleidoscopic" set of changes in the persons and parties leading the states has made it difficult for the state and center to build meaningful relationships).

346. Mukhopadhayay, supra note 15, at 67.

347. THIRTEENTH FIN. COMM'N OF INDIA, supra note 48, at 160.

348. Twelfth Five Year Plan - Volume II, supra note 103, at 331 (calling for strengthening municipal finance through the creation of robust tax and non-tax based revenue streams, by attracting private capital to the urban sector, and by systematically monetizing land); MOHANTY ET AL., supra note 2 , at $1-2$.

349. GOV'T OF INDIA SECOND ADMIN. REFORMS COMM'N, supra note 2, at 51.

350. Kennedy \& Zerah, supra note 71, at 113. 
The 74th CAA envisioned that municipalities would be more financially robust and that their long-term sustainability would depend on greater financial authority. ${ }^{351}$ But decentralization is not fiscally neutral. Rather, it entails an additional burden on the states, requiring additional financing to achieve higher levels of service delivery and staffing. ${ }^{352}$ For example, certain powers, such as accounting and using GIS to improve property taxation, require an investment in technical skills and equipment, which were not funded under the JnNURM. ${ }^{353}$ Moreover, fiscal decentralization also requires a certain degree of flexibility through untied resources. The inherent asymmetry in a fiscal federalism system requires that local authorities be able to establish priorities, create new schemes, and allocate funds. ${ }^{354}$ While funding under the JnNURM was earmarked for infrastructure development and basic services, there has not been a similar earmarking of funding to assist with devolution of power.

Calls to restructure the system of municipal finances in the country have been made. ${ }^{355}$ Various studies commissioned by India's central government have urged that the Constitution be amended to specifically create a "Local Bodies Finance List" Schedule." ${ }^{357}$ It has also been suggested that a "special purpose vehicle" be

351. GOV'T OF INDIA SECOND ADMIN. REFORMS COMM'N, supra note 2, at 223.

352. THIRTEENTH FIN. COMM'N OF INDIA, supra note 48, at 161.

353. THORNTON, supra note 103, at 257-58.

354. GOV'T OF INDIA SECOND ADMIN. REFORMS COMM'N, supra note 2, at 17, 60.

355. MOHANTY ET AL., supra note 2, at ix (suggesting a long list of reforms including "revisiting expenditure assignment and revenue assignment, finding an alternative to Octroi, developing national consensus on a Municipal Finance Schedule, careful matching of revenues and expenditures based on Bahl-Linn principles, raising local revenue efforts, reforming property tax, using urban land as a resource, adopting 'users pay', 'beneficiaries pay' and 'polluters pay' principles, linking individual services with user charges and collective services with benefit taxes, restructuring inter-governmental transfers with a simple distributive formula that gives due weights to needs, rights to minimum basic services, incentives to performance and inter-jurisdictional equity, easing borrowing restrictions on ULBs, financing urban infrastructure through exploring the options of i) specialized banks for municipal lending, ii) municipal bond markets, and iii) specialized municipal funds and strengthening the creditworthiness of ULBs, developing public-private partnerships, addressing poverty alleviation through linkage to buoyant redistributive taxes, improving expenditure management and disclosure, promoting fiscal responsibility and professionalizing municipal management").

356. HPEC REPORT, supra note 47, at 129 (also outlining other ways that the constitution can be amended, such as by enabling urban local bodies to exclusively levy certain taxes (property, profession, entertainment, and advertisement) and to constitutionally mandate a revenue-sharing formula).

357. See THIRTEENTH FIN. COMM'N OF INDIA, supra note 48, at 158 (noting that a proposal to transfer a share of the divisible pool directly to the local bodies would "vitiate the Constitutional mandate that the Finance Commission recommend augmentation of the consolidated fund of the states on the basis of the recommendations of the SFCs"); GOV'T OF INDIA SECOND ADMIN. REFORMS COMM'N, supra note 2, at 227 (noting that the National Commission to Review the Working of the Constitution "recommends that the Eleventh and the Twelfth Schedules should be restructured in a manner that creates a separate fiscal domain for Panchayats and Municipalities. Accordingly, Articles 
created by the national government to release funds directly to municipalities, thereby bypassing the state. ${ }^{358}$ However, it may not be practicable to amend the Constitution to create a separate tax domain for local governments. ${ }^{359}$ Municipalities do not have the capacity to collect such taxes, and these proposed changes may have an adverse impact on the financing of State Plans. ${ }^{360}$ The need for greater cooperative federalism is clear.

There is need for improvement in the relations between all branches of India's government. Of particular importance, however, is the relationship between the federal government and the states. This analysis highlights the extent to which the federal government's efforts at decentralization have been stymied by state government reluctance to devolve power. A greater effort needs to be made by the federal government to assess whether this reluctance is related to a lack of capacity at the municipal level. The federal government should work with the states to identify powers that could be feasibly devolved to municipalities. The federal government should also counsel states on the importance of pursuing fiscal and political decentralization together. If power is devolved before financing, the local government will not be able to exercise its functions appropriately. If financing is devolved before power, then municipalities may simply become more wasteful in their spending. In order to achieve effective decentralization and cooperative federalism, greater consultation between the federal and state governments is necessary.

\section{CONCLUSION}

Cities are increasingly important actors in the global economy. Projected to have the fastest rate of urban growth, India presents a fascinating case study for understanding how the constitutional fabric in which cities are embedded influences their capacity to be autonomous legal actors. Moreover, with the landslide 2014 election of Prime Minister Modi, India is now poised to launch a series of new urban renewal schemes and

$243 \mathrm{H}$ and $243 \mathrm{X}$ should be amended making it mandatory for the Legislature of the States to make laws devolving powers to the Panchayats and Municipalities."); MOHANTY ET AL., supra note 2, at ix, 1 (“A 'Municipal Finance Schedule' for assignment to the ULBs to match the list of functions included in the 12th Schedule may comprise property tax including vacant land tax, taxation of Central and State Government properties (or service charges in lieu thereof), professional tax, entertainment tax, advertisement tax, business licensing fee or tax, motor vehicle tax or a share from the same, planning permission fee, development impact fee, betterment levy, a surcharge on stamp duty on registration deeds or a share from it and a proportion of the Value Added Tax.").

358. THORNTON, supra note 103 , at 268 .

359. GOV'T OF INDIA SECOND ADMIN. REFORMS COMM'N, supra note 2, at 227.

360. Id. 
has already secured support from the U.S. for its "Smart Cities" program. Now is a critical time for understanding the lessons of prior efforts to promote decentralization and urban renewal.

Through the 74th Constitutional Amendment Act, India paved the way for a dramatic shift in power to urban local bodies. Decentralization presented an opportunity to enhance grassroots democracy by bringing power closer to the people and to improve urban areas through allocative efficiency gains. Although the 74th CAA was enacted in 1992, it was not until 2005 that the government of India began to meaningfully implement it through the JnNURM. This national urban renewal scheme represented a historic policy shift because it tied urban infrastructure and service delivery improvements to decentralization-oriented governance reforms at the state and local levels. Yet many of the expected gains did not materialize. This article argues that this failure is due in large part to India's constitutional structure and to the way that decentralization under the 74th CAA has been pursued.

Decentralization has not yet been successful in India for three key reasons. First, decentralization has only been partially implemented: the language of the constitutional amendment has hindered effective political decentralization, the comparative advantage of parastatal agencies has made administrative decentralization difficult, and the devolution of responsibility - but not revenue - to municipalities has hampered fiscal decentralization.

Second, the analysis has revealed an irony: it has taken a highly centralized policy like the JnNURM to motivate devolution of power from states to local bodies under the 74th CAA. But this top-down approach has reduced the importance of local decision-making, thereby mitigating the allocative efficiency gains of decentralization. For example, the JnNURM tied funding to mandated reforms at the state and local levels, inadvertently exacerbating relations with the states.

The third factor has been the relative weakness of local governance structures, which has created a Catch-22 situation. Without the necessary administrative capacity and financial resources, states are not going to devolve political power to municipalities. Investing in cities may require slowing down the decentralization process in the short-run by providing city managers with the skills and training necessary for meaningful involvement in the planning process, as opposed to rubber-stamping projects. This might mean that projects come to fruition more slowly, but it could mean better-run projects in the long-run. Improving the capacity of local governments is a key step to ensuring greater political, administrative, and fiscal decentralization. 
In order for decentralization to succeed in India, more effort needs to be directed towards developing an effective model of cooperative federalism. The central government does not have a direct relationship with local bodies: it must work through the states. As a result, it needs to collaborate with the states to identify which powers could be feasibly devolved to municipalities and to develop solutions for perceived barriers to that devolution. Under India's constitutional structure, the central government will only be able to achieve the vision of decentralization embodied in the 74th CAA if the states are willing partners in the endeavor. 